\title{
Human Rights and Southern Realities
}

Tamara Relis

Touro Law Center

Follow this and additional works at: https://digitalcommons.tourolaw.edu/scholarlyworks

Part of the Human Rights Law Commons

\section{Recommended Citation}

33 Hum. Rts. Q. 509 (2011).

This Article is brought to you for free and open access by the Faculty Scholarship at Digital Commons @ Touro Law Center. It has been accepted for inclusion in Scholarly Works by an authorized administrator of Digital Commons @ Touro Law Center. For more information, please contact Iross@tourolaw.edu. 


\title{
HUMAN RIGHTS QUARTERLY
}

\section{Human Rights and Southern Realities}

\author{
Tamara Relis*
}

Human Rights, Southern Voices: Francis Deng, Abdullahi An-Na'im, Yash Ghai, Upendra Baxi (William Twining ed., Cambridge Univ. Press, 2009) 248 pages, ISBN 9780521130264 and Helen M. Stacy, Human Rights for the 21st Century: Sovereignty, Civil Society, Culture (Stanford Univ. Press, 2009) 280 pages, ISBN 9780804760959.

\section{INTRODUCTION}

The proliferation of international human rights treaties, committees, and courts, and the development of human rights norms and standards over the last sixty years represent immense achievement. International human rights laws and principles are now asserted throughout the world by individuals

\footnotetext{
* Tamara Relis is an Assistant Professor of Law, Touro Law School, New York and a Research Fellow at the London School of Economics, Department of Law. LL.B (hons) University of London, LL.M (hons) and Ph.D. (law), London School of Economics Department of Law. Postdoctoral Research Fellow, Columbia Law School, New York and London School of Economics (2005-09), Barrister.

This essay draws on preliminary analysis of empirical research conducted in eight states of India during 2005-2009 subsequent to funding through British Academy Award PDF/2006/64 and two postdoctoral research fellowship awards at the London School of Economics Department of Law and Columbia University Law School: Economic Social Research Council Award PTA-026-27-0979. I would like to thank profusely my eight teams of research assistants throughout India. Their names are unfortunately too many to list, but without them this research would not have been possible. I would also like to thank Karen Knop, Leila Sadat, Mark Weisburd, Winston Nagan, Jordan Paust, Aziza Amed, Timothy Kaye, Paul Brietzke, Fabio Arcila Jr., Rodger Citron and Anna Cheszes for their insightful comments on drafts of this essay, and Brian Shupak for his excellent research assistance in New York. Parts of this essay were presented at the American Law \& Society Annual Meeting, Denver (2009), the International Symposium on Victimology, Mito, Japan (2009), the IVR World Congress of Philosophy of Law, Beijing (2009), Cornell Law School (2010), and the UNDP (2010).
} 
of many cultures and traditions. Yet, at the same time human rights ideas continue to have difficulty in manifesting their relevance in the daily lives of those who are geographically and culturally distant from international institutions. ${ }^{1}$ Thus, the international human rights regime has arguably reached a juncture that demands a reoriented view responding to the disparities between human rights laws and principles on the one hand, and realities on the ground for many of the subjects of human rights on the other. ${ }^{2}$ While scholars have noted this discontinuity, particularly for those in the global South, few have attempted to realistically respond to this. Two new booksWilliam Twining's Human Rights, Southern Voices: Francis Deng, Abdullahi An-Na'im, Yash Ghai, Upendra Baxi, (Southern Voices) and Helen Stacy's Human Rights for the 21st Century (21st Century)_address aspects of this paradox, and lay the foundations for exciting changes in the international human rights regime in the twenty-first century.

Southern Voices is unique in that it provides important perspectives from four renowned non-Western legal scholars-Deng (Sudan), An-Na'im (Northern Sudan), Ghai (Kenya), and Baxi (India). The authors offer timely insight into societies and cultures of the global South in terms of their interests, concerns, and perspectives on human rights. The authors are realistic about the obstacles involved in reconciling the discourse of human rights with many of the practices relating to human rights issues around the globe. Yet, they provide concrete advice on how to advance towards realizing the vision of international human rights. Their insights highlight the cosmopolitan reality of the current human rights regime. They also underscore the need for greater incorporation of Southern views and traditions into the discourses on human rights within any legitimate international order. ${ }^{3}$

21 st Century addresses the main critiques of international human rights, specifically cultural pluralism, sovereignty and civil society. The book additionally proposes the development of a hybrid regional human rights court system, interstitially positioned between international human rights institutions and national courts. Such regional courts, Stacy argues, respond to the issue of the universality of human rights, as their unique position allows them to integrate international treaty principles with the realities of cultural pluralism and diverse local practices. The hybrid regional courts would simultaneously promote and improve human rights norms across cultures and political and social orders, while honoring social, cultural, and religious values and mediating these different values through principles and process. ${ }^{4}$

1. Helen M. Stacy, Human Rights for the 21 st Century: Sovereignty, Civil Society, Culture 3-4, 44, 171 (2009); Human Rights, Southern Voices: Francis Deng, Abdullahi An-Na'im, Yash Ghal and Upendra Baxi 163 (William Twining ed., 2009) [hereinafter Southern Volces].

2. STACY, supra note 1 , at 173 .

3. SOUthern Volces, supra note 1 , at 1 .

4. Stacy, supra note 1 , at 32, 171. 
This essay provides a critical account of some important remaining gaps in the literature on international human rights theory and practice. It argues that relatively little scholarship, including both reviewed books in their discussions on human rights praxis, grounds its analysis in the discourse of the subjects of international human rights law, particularly those people actually involved in human rights violations in the developing world. This is notwithstanding the fact that a main function of the international human rights movement is to give voice and power to those oppressed. Further, the meaning of human rights must be grounded in local culture at grassroots levels. Top-down textual and theoretical analyses relating to human rights practice cannot adequately capture the textured realities and complexity of factors involved. Consequently, bottom-up perspectives from local actors must be incorporated to additionally inform and possibly reframe macrolevel scholarly conversations on human rights as well as policies aimed at improving respect for human rights at grassroots levels.

Given that the "global South" is extremely diverse, questions such as, "What are victims' and legal actors' conceptions and expectations of human rights? What are their agendas and experiences in processing their cases in various justice systems?" and "What factors affect their attitudes and behavior in this context?" need to be asked in many locations. ${ }^{5}$ Further, actors' perceptions on these issues must be interwoven with information on local social contexts, structures, and interactions. Contextualized, interpretive accounts from those embroiled in human rights cases are critical to obtain a comprehensive picture of the workings of international human rights on the ground and to enable a more nuanced understanding of Southern actors' needs, epistemologies, and micro-realities. ${ }^{6}$ Such micro-realities regularly include webs of family, kin, and community. These networks include social norms, exert influence and affect actors' understandings, attitudes, and conduct in relation to human rights issues. Yet, international human rights law and scholarship have not been adequately infused with these realities. ${ }^{7}$ This is notwithstanding the fact that data

5. For example, it has been argued and shown in the context of dowry murders in India that the issue of women's rights must be understood from the perspectives of women in the global South. See Meghana Shah, Rights Under Fire: The Inadequacy of International Human Rights in Combating Dowry Murder in India, 19 ConN. J. INT'L L. 209, 227 (2003). Clearly there are inherent risks in extrapolating without qualification from one location to another. Thus, this essay makes no claims as to the representativeness of the present data in terms of other individuals and societies in developing nations.

6. In terms of local actors' epistemologies, what people know, how their knowledge is acquired, and how their knowledge and social situations affect their beliefs and actions relating to human rights require further investigation. See, e.g. Andrew K. Woods, A Behavioral Approach to Human Rights, 51 Harv. INT'L L.J. 51, 51-52, 55-56, 71, 73, 78-79, 95, 98 (2010).

7. In advocating a new approach to international human rights to include findings from behavioral studies, Woods highlights the fact that the human rights academic and practice literature has been focused on state behavior. Consequently, what is lacking is an empirically-based documented exposition of the ways in which social situations are influenced by and/or give meaning to human rights laws, shape and regulate conduct related to human rights and how such situations can be altered. See, e.g., id. at 73-74 (2010). 
from psychological research indicate that individuals are greatly influenced by their social situations, whether they are aware of it or not. ${ }^{8}$ Knowledge at this level has the capability to inform and enrich macro-level conversations on human rights, but equally to change them. Such knowledge can further assist human rights practitioners and architects to enhance policies aimed at improving respect for human rights on the ground.

This essay offers some such data from a forthcoming book grounded in interpretive theory and based on new large-scale empirical research into the perspectives of legal and lay actors involved in the processing of human rights violation cases of violence against women in eight states of India. These cases were processed in either lower formal courts or in quasilegal non-state justice regimes. ${ }^{9}$ Actors' objectives, meanings and practices act as a lens to map, theorize and critically analyze some of the debates in the human rights literature, including those set out in the two volumes reviewed here. The essay shows that notwithstanding state enactments of laws in line with international human rights obligations, as well as the dissemination of human rights concepts by transnational activists and domestic nongovernmental organizations (NGOs) who work to make them meaningful within particular societies, victims of violence generally showed little if any human rights "emancipation." This was underscored in their discourse on their motivations and agendas in approaching formal courts and quasi-legal regimes. Further, despite developments in the higher courts of India, many lawyers and judges operating in the lower courts and court-linked media-

8. See Lee D. Ross, The Intuitive Psychologist and His Shortcomings: Distortions in the Attribution Process, in Advances In Experimental Social Psychology: Vol.10, 173 (Leonard Berkowitz ed., 1977). See also Dan T. Gilbert \& Patrick S. Malone, The Correspondence Bias, 117 Psychol. Bull. 21, 21-38 (1995), cited in Woods, supra note 7, at 56; Cristina Bicchieri, The Grammar of Society: The Nature and Dynamics of Social Norms 3, 80 (2005), cited in Woods, supra note 7, at 54, 57. See also Woods, supra note 7, at 58, 70.

9. Tamara Relis, Human Rights and Legal Pluralism: Theory, Global Standards, and Southern Actors' PrACTICE (forthcoming 2012). The book draws on qualitative, partly ethnographic empirical fieldwork research during 2005-2009 in eight states of India: Delhi, Mumbai and rural Jalna (Maharashtra), rural Saketri (Haryana), Bangalore and rural Bijapur and Ramnagaram (Karnataka), Hyderabad (Andhra Pradesh), Jaipur and Jodhpur (Rajasthan), Lucknow (Uttar Pradesh) and Guwahati (Assam). With the assistance of over eighty local research assistants working in seven languages, the data derive from over 400 semi-structured interviews and questionnaires from victims (94), accused (46), family members (29), lawyers on all sides (86), judges and judge-mediators (30) and non-state justice arbitrators ("panches")(48) in 200 cases. It also includes eighty-three observations of case hearings in lower criminal and civil courts (magistrates, sessions, district, and family courts), court-linked mediations known as "lok adalats" (in lower and high courts) and non-state womens' courts/arbitrations known as "mahila panchayats" and "nari adalats." The mahila panchayats and nari adalats are run under the auspices of domestic NGOs "Action India" and "Mahila Samakya" respectively throughout the north and south of India. The data additionally include fifty-five contextual interviews with public interest lawyers, local legal scholars, human rights commission officials, human rights NGOs, and national and state legal services authority judges (who organize the lok adalats) in Delhi, Mumbai, Pune, Bangalore, and Hyderabad. 
tions known as lok adalats (i.e. "peoples' courts" where large numbers of gender violence cases are heard) did not feel that international human rights principles, including those articulated in CEDAW, were directly relevant to their cases. Instead, mainly local traditions were used in case resolution.

Victims with little education had either never heard of human rights or lacked an understanding of their meaning. More educated victims who had a general sense of human rights concepts knew little of specifics. Of course, in analyzing the permeation of international human rights in various cultural contexts unfamiliarity with the term "human rights" need not be important in itself. However, interestingly, the discourse of both groups generally indicated that fundamental human rights principles such as equality and autonomy were of little relevance to their life situations and indeed perceived as such. Those more educated viewed human rights to be positive, but primarily of use on an inspirational level. Many less educated victims of violence enlisted quasi-legal justice systems as a means of obtaining compromise agreements with their abusers in order to peacefully return to or remain in their places of abuse; these were commonly the joint family homes of their spouses. Victims' desires were colored not only by their economic situations, but also by their not wanting to harm the honor of their families of origin. Indeed, although this may in some ways be harmful to women, it is well-established that the bulk of individuals in most non-Western cultures define themselves as members of larger groups or communities, not as autonomous entities. ${ }^{10}$ Consequently, concepts such as individual rights can be perceived as alien or problematic. Interestingly, victims' comprehensions of human rights and stated motivations for and perceptions of "justice" regularly corresponded with those of their family members who also participated in the hearings and were interviewed separately.

On the basis of these and other similar findings from the dataset, this essay first argues that human rights understandings, subjectivities, and objectives of victims of violence in the Indian landscape-and probably in many traditional societies in developing contexts - are bound up intricately within social and cultural structures including networks of family, kin, and community. This enculturation within particular societies is complicated by factors of poverty, illiteracy, and development. ${ }^{11}$ Indeed, for many in traditional societies the ex-

10. Claude Ake, The African Context of Human Rights, 34 Afr. Today 5 (1987). See also Josiah A.M. Cobbah, African Values and the Human Rights Debate, 9 Hum. Rts. Q. 309 (1987); Radhika Coomaraswamy, To Bellow Like a Cow: Women, Ethnicity, and the Discourse of Rights, in Human Rights of Women: National and International Perspectives 39 , 39 (Rebecca J. Cook ed., 1994); Eva Brems, Enemies or Allies? Feminism and Cultural Relativism As Dissident Voices in Human Rights Discourse, 19 Hum. Rts. Q. 136, 142, 145 (1997).

11. Poverty, as defined by the poor, includes not only being materially or resource poor, but also dependent, feeling helpless, humiliated by state and non-state actors, and acutely vulnerable. Poverty further includes being ill-informed and lacking in social connections, thus disempowered. See generally Deepa Narayan et al., Voices of the Poor: Can Anyone Hear Us? (2000); Deepa Narayan et al., Voices of the Poor: Crying Out For Change (2000). 
tended family and immediate community provide social security while stressing responsibilities and collective duties for members. They socialize and impart values, simultaneously controlling and disciplining their members including arbitrating and mediating conflict. ${ }^{12}$ The associated norms within these social conditions perform a regulatory function that constrains individuals' behavior through community enforcement. ${ }^{13}$ Understanding and taking greater account of the dynamics of these overlapping normative, rule-encompassing social fields is a necessary prerequisite to theorizing and resolving issues relating to the practice of human rights. These social fields range from state or customary law to socio-legal spaces including community, family, or other groups in which individuals are constituted and socialized..$^{14}$

Second, the essay additionally argues that on the basis that a culturally plural universalism in human rights is an acceptable aim, there is a dire need for a new integrated analytical framework. This framework must be grounded not only in the perspectives of Southern actors or those oppressed, but must simultaneously imbed their epistemologies within the realities of human rights case processing in the legally pluralistic global South. This involves not only formal courts but also quasi-legal non-state justice systems processing human rights cases. Understanding local case processing nuances is important in analyzing the acceptance and application of international human rights at grassroots levels. For example, further findings suggest that lawyers and judges processing gender violence cases in the lower courts employed human rights principles to a far lesser extent, if at all, than did many quasi-legal arbitrators in the women's courts (mahila panchayats) who had not received any formal legal education and often had poor literacy skills.

Indeed, throughout much of the developing world, large numbers of criminal and civil cases, including those involving human rights violations, are not taken to formal justice systems for various reasons. These reasons include lack of knowledge of courts, rights or how to formulate claims, illiteracy, problems of access including physical distance and lack of resources, and fear or lack

In May 2001, the United Nations Committee on Economic, Social and Cultural Rights (CESCR) defined poverty as "a human condition characterized by sustained or chronic deprivation of the resources, capabilities, choices, security and power necessary for the enjoyment of an adequate standard of living and other civil, cultural, economic, political and social rights." Committee on Economic, Social and Cultural Rights, Report of the Twenty-fifth Sessions, U.N. ESCOR, Comm. on Econ., Soc. \& Cult. Rts., 25th Sess., I 8, U.N. Doc. E/C.12/2001/10 (2001), cited in Marguerite Garling, Int'l Council on Human Rights Policy, Enhancing Access to Human Rights 1-2, 9 (2004). By subjectivity, I am referring to a person's feelings, beliefs, and desires relating to human rights, shaped by the concepts of autonomy, equality and choice.

12. GarLING, supra note 11 , at 51 .

13. See Lawrence Lessig, The New Chicago School, 27 J. Legal Stud. 661, 662, 677 (1998). See also Woods, supra note 7, at 54, 76; Bicchierl, supra note 8, at 3.

14. See Relis, Human Rights And Legal Pluralism, supra note 9. 
of trust in the formal justice system. ${ }^{15}$ The poor and marginalized as well as others may also reject official institutions for historical and cultural reasons. ${ }^{16}$ Formal courts may seem intimidating, alien, and frightening. Additionally, many formal justice systems include structural impediments to the full realization of human rights. These impediments consist of uneven resource allocation, criminality, patronage and nepotism, ignorance and ineptitude, and various biases including those of class, caste, ethnicity, and gender. ${ }^{17}$

In the context of India it has been argued that issues of social stratification coupled with geographic isolation result in the formal legal system frequently being accessible only to the middle and upper classes. Even those who are aware of legal remedies are usually disinclined to pursue them. There are also issues of police corruption and fear of social repercussions, which impede access to formal justice systems. ${ }^{18}$ Thus, although human rights law makes the state the main mechanism for social protection, the poor and marginalized are often ambivalent toward state institutions, with many viewing the law as a vehicle for powerful interests. Consequently, they often choose to place their trust in informal and customary processes, which may be perceived as accessible, familiar, low-risk, and culturally comfortable. Hence, many cases involving human rights are settled through quasi-legal, non-state mechanisms of conflict resolution in various forms. ${ }^{19}$

The reliance on quasi-legal, non-state mechanisms in human rights cases is also insufficiently examined in the international human rights literature, including both reviewed books. As Erika Techera notes, "International law plays an important part in establishing norms and standards that inform national law and policy. However, it has failed to effectively address many of

15. Call for Research Papers, UNDP Regional Centre Bangkok: Engaging State Institutions to Enable Non-State Justice Systems to Provide Access to Justice-the Formal/Informal Interface (2010), available at http://regionalcentrebangkok.undp.or.th/whatsnew/ documents/20100610-ResearchPaper.pdf. These have been discussed as overlapping and mutually reinforcing sources of disempowerment, which may deny rural people access to courts. Poverty also prevents people from accessing their rights. See GarLING, supra note 11, at 1-2; see also P.N. Sankaran, Participatory Justice and Human Rights Protection In Little Democracies: A Pilot Study 10, 30-31 (2003); Shah, supra note 5 at 221, 224-25, 228; Robert S. Moog, The Politics of Lok Adalats in Varanasi District, 25 Law \& Soc'Y Rev. 545, 549-51, 563-64 (1991); Marc Galanter \& Jayanth K. Krishnan, "Bread for the Poor": Access to Justice and the Rights of the Needy in India, 55 Hastings L.J. 789, 807, 827, 833 (2004); Veronica Magar, Empowerment Approaches to Gender-Based Violence: Women's Courts in Delhi Slums, 26 Women's Stud. INT'L F. 509, 510 (2003); Interview with Dr. Neela Mukherjee, UNDP, in New Delhi, India (21 July 2006); Interview with Veena Punacha, SNDT, in Pune, India (31 July 2006); A. Chowdhury, Protection of Women from Domestic Violence Act 2005: Balancing Gender Equations, 27 DelHI L. Rev. 98, 98 (2005); Karine Bates, Paper Presentation at the Annual Meeting of the Law and Society Association: Legal Consciousness and Informal Transmission of Legal Knowledge in India (28 May 2010).

16. GarLing, supra note 11 , at 2,7 .

17. Id. at 13,54 .

18. Shah, supra note 5 at 221, 224-25, 228.

19. See sources cited supra note 15 . 
the specific needs of legally pluralist nations." ${ }^{20}$ Indeed, the nexus between international human rights and legal pluralism is in need of far greater examination in the legal literature. Although human rights permeation and legal pluralism are interrelated, their relationship is complex. Thus, one might argue that to be accepted in a pluralistic environment, human rights norms might need to be expressed in another idiom. ${ }^{21}$

Through normative arguments and concrete cases, the essay demonstrates how at the center of the two books lies a new way to innovatively engage the controversies in international human rights theory and practice, and that these issues must factor directly into any holistic assessments, critical analyses, or proposals for the development of the international human rights regime in the twenty-first century. Drawing on insights from both books, the essay concludes with a call for more research into Southern actors' human rights perspectives, including interpretive accounts of their contextual realities. Such knowledge is critical in order to innovatively engage the controversies in international human rights theory and practice and to assist human rights organizations and advocates to become more valuable to the poor and the oppressed. As such, they will be better able to effect realizable change for the subjects of human rights in the global South. ${ }^{22}$

Part II of this essay sets out the main arguments developed in each of the books relating to present issues in international human rights. Part III links actors' understandings and objectives as well as both volumes' arguments on human rights practice to theoretical developments in the interdisciplinary literature on international human rights: norm diffusion theory in the international relations and sociolegal studies literatures and vernacularization theory in the law and anthropology literature. Like both reviewed books, these theoretical developments engage the issue of the permeation of human rights standards to grassroots levels. ${ }^{23}$ In so doing, Part III highlights important gaps

20. Erika Techera, Strengthening International Law to Address the Needs of Legally Pluralist Nations (Macquarie University-Macquarie Law School, Australia, Working Paper No. 2010-02, 2010), available at http://ssrn.com/abstract=1545528.

21. Email from Karen Knop, University of Toronto School of Law (20 Mar. 2011) (on file with author). Some interesting works include, Abdullahi An-Na'im, Protecting Human Rights in Plural Legal Systems in Africa: A Comparative Overview, in UnIVERSAL Human Rights, Local Remedies 39-64 (Abdullahi An-Na'im ed., 1999); Paul Schiff Berman, Global Legal Pluralism, 80 S. CAL. L. Rev. 1155 (2007); Paul Berman, The New Legal Pluralism, 5 Ann. Rev. L. \& Soc. ScI. 225 (2009); see also Techera, supra note 20.

22. The latter need has been noted by the International Council on Human Rights. See GARLING, supra note 11 , at 3 .

23. See Thomas Risse \& Kathryn Sikkink, The Socialization of International Human Rights Norms into Domestic Practices: Introduction, in The Power of Human Rights: International Norms and Domestic Change 1-5, 7-8, 11, 33 (Thomas Risse, Stephen C. Ropp, \& Kathryn Sikkink eds., 1999); see also Margaret E. Keck \& Kathryn Sikkink, Activists Beyond Borders: Advocacy Networks in International Politics (1998); Kathryn Sikkink, Human Rights, Principled Issue-Networks, and Sovereignty in Latin America, 47 INT'L Org. 411 (1993); Sally E. Merry, Human Rights and Gender Violence: Translating International Law into local Justice 1, 3, 134, 222 (2006) [hereinafter Human Rights and Gender Violence]; Sally Engle 
in the human rights literature and makes the argument for greater inclusion of both ordinary Southern voices and typical Southern realities involving legal pluralism within the human rights debates. ${ }^{24}$

Providing data for reflection on some of the arguments proffered in the essay, Part IV examines human rights permeation and realities for female victims of violence in India who processed their cases in either lower formal courts or quasi-legal non-state justice systems. Legal and quasi-legal actors' discourse in these cases is also highlighted. Drawing on these examples, Part $V$ sets out both volumes' proposals for the future, analyzing their important contributions, as well as underscoring some of the remaining gaps in the theoretical and practical literature on international human rights.

\section{PRESENT CONDITIONS AND DISCONTENTS IN HUMAN RIGHTS}

Southern Voices and 21st Century update our understanding of international human rights law theory and practice. The books engage the central debates about the nature and practice of human rights law. Yet, they ground their analyses in the important fact that international human rights principles and standards are normatively rooted in conceptions of human dignity, which vary with cultural perspectives. ${ }^{25}$ The books additionally offer important insights to facilitate greater permeation and grassroots legitimacy of international human rights norms and standards. The authors proffer evolutionary explanations on the issues of cultural pluralism and the changing nature of the international human rights regime. Their views provide a lens through which to understand and address the limits of existing human rights policies and mechanisms. These two ambitious volumes are innovative and are among the first book-length attempts by the legal community to constructively address issues of human rights practice throughout the globe. This part examines the main arguments in both books on current discourses and practices related to the international human rights system.

In terms of the present, 21 st Century provides accounts of the development, obstacles, and main critiques of the international human rights regime. ${ }^{26}$ Similar to the authors in Southern Voices, Stacy notes the disparity between human rights objectives and grassroots realities. She observes how international human rights laws and standards have grown exponentially since the Universal Declaration of Human Rights (UDHR) in 1948. They are included

Merry, Transnational Human Rights and Local Activism: Mapping the Middle, 108 Ам. Anthropologist 38, 42, 49 (2006); Sally Engle Merry, Rights Talk and the Experience of Law: Implementing Women's Human Rights to Protection from Violence, 25 Hum. RTs. Q. 343, 379 (2003).

24. See Risse \& Sikkink, Introduction, supra note 23, at 1-5, 7-8, 11, 33; MerRy, Human Rights And Gender Violence, supra note 23.

25. See, e.g., SOUthern Voices, supra note 1, at 37.

26. STACY, supra note 1 , at 14-21, 28-29, 33-35. 
in many postcolonial constitutions and are asserted globally by governments, NGOs, and individuals of numerous cultures, traditions, and socioeconomic groups. Human rights are likewise relied upon in the global economy and are utilized as indicators of legitimacy for new governments. ${ }^{27}$ At the same time, states frequently do not honor their treaty and other international obligations by not including human rights in their domestic laws and policies or enforcing them in their court systems. Thus, human rights abuses occur worldwide. Consequently, the international human rights system is critiqued by both local organizations as well as scholars. ${ }^{28}$

As part of addressing these inconsistencies and advancing a new legal mechanism involving hybrid regional courts to operationalize human rights, 21 st Century analyzes three central critiques of international human rights today. These are referred to as the sovereignty, civil society, and multiculturalism or cultural pluralism critiques. Stacy responds to each one in depth, illustrating that although these critiques highlight material problems with the present workings of the international human rights system, each critique lacks key information. ${ }^{29}$ The sovereignty critique on the political right argues that international human rights are either weak rhetoric in the face of national self-interests or are a justification for colonial or imperial ventures that threaten the integrity and independence of nation-states. ${ }^{30}$ In response to and in light of the ramifications on sovereignty as a result of globalization (particularly economic and electronic), Stacy argues that sovereignty in today's realities of global interdependence should be comprehended as relational and humanitarian, and not autonomous. ${ }^{31}$ The civil society critique argues that in our globalized world non-state actors, including civil society, NGOs, and corporations are more effective and have overtaken formal legal institutions in instituting real human rights change. They do so through bottom up persuasion of governments and international entities. Stacy notes that the empirical evidence on this is controversial, and asserts that though important these activities have not overtaken law in effecting social change. For instance, NGO activities have worked in conjunction with legal institu-

27. Id. at $4,26-28$.

28. Id. at $1-6,26$.

29. Id. at 4-5, 13, 29-30.

30. Some argue that international human rights have negative effects or are actually a type of global subjugation or neo-imperialism based on European legal and political thought and recreating the individualism of Western cultures, which is foreign to others. Mutua has argued that "the globalization of human rights fits a historical pattern in which all high morality comes from the West as a civilizing agent against lower forms of civilization in the rest of the world." StACY, supra note 1, at 4 (citing Makau Mutua, Savages, Victims and Saviors: The Metaphor of Human Rights, 42 HARV. INT'L L.J. 201, 210 (2001)).

31. Stacy, supra note 1, at 13, 30-31, 109-40. 
tions, which are needed to formalize rules. ${ }^{32}$ The multiculturalist critique on the political left that speaks to the universalism versus cultural relativism debates argues that endeavors to institutionalize "universal" human rights are problematic, imperialist, oppressive, and insensitive to cultural multiplicity. Moreover, systems in the global South with divergent cultural norms have different human rights priorities. ${ }^{33}$

In response to these critiques, Stacy argues that an examination of normative, practical, and historical realities, coupled with changes in international relations suggests an institutional response. In our swiftly evolving world order we require a more robust human rights design to tackle both sovereignty and diverse cultural traditions. In particular, legal institutions and methodologies should be adapted to meet current realities. ${ }^{34}$ As it relates to the future, Stacy's proposal for a new hybrid regional international human rights court system is elaborated upon in Part $\mathrm{V}$ below.

Southern Voices contains excerpts from the authors' various writings and offers important non-Western perspectives on the interests, beliefs, concerns, and customs of those in the global South. These have been largely absent in Western jurisprudence. In providing unique insight on the debates on universalism versus cultural relativism in human rights theory, all four authors discard relativism as a serious challenge. Instead, they strongly advocate a type of universalism that is grounded in cultural pluralism. ${ }^{35}$ Cultural relativism broadly reflects the idea that individuals' beliefs and actions must be understood in terms of their own cultures. In contrast, cultural pluralists argue that there are certain universal human rights standards. However, these universal standards must be interpreted in diverse ways by different cultures. This practice accords with much recent literature that now dismisses the cultural relativism versus universalism debates, urging us to move forward as particular strands of cultural relativism oversimplify the complexity and fluidity of local cultures and moral norms within particular groups or mask power relationships and coercion. ${ }^{36}$ Thus a multicultural, cross-cultural, or

32. Id. at 10, 11 n.14, 29, 31. In line with Stacy, Ghai too notes that the legal structures of human rights are increasingly and often exclusively the means to mobilize social protests and demands and to critique social relationships and institutions.

33. Id. at 8, 12-13, 29-30. For instance, in the "Asian values" debate Singapore's former Prime Minister, Yew, argued that human rights should be understood through Confucianism and that Asian values put social and economic rights ahead of individual rights. Id. at 12 n.21.

34. Id. at 4, 5, 171.

35. This coincides with Mutua's categorization of "multiculturalists" in the human rights literature. See Makau Wa Mutua, The Ideology of Human Rights, 36 VA. J. INT'L L. 589, 598 (1996).

36. See, e.g., Conor Gearty, Are Human Rights Truly Universal?, in Essays on Human Rights on Terrorism: Comparative Approaches to Civil Liberties in Asia, the EU and North America ch. 29 (2008); see also Rosalyn Higgins, Problems and Process: International Law and How We Use It 96 (1994); Henry J. Steiner, Philip Alston \& Ryan Goodman, International Human Rights in 
culturally plural conception of human rights is advocated whereby conceptual human rights principles are to be supplemented, informed, or contextualized by culture or tradition. ${ }^{37}$ As such, the objective is for all principal cultural groups worldwide to contribute in a meaningful way to decisions on the normative content of human rights law. ${ }^{38}$

Deng's writings provide rare insight into the history and realities of the Dinka of Sudan. As a Dinka member, Deng elucidates the Dinka's world views, self-perceptions, values, social norms, notions of respect, and patterns of behavior within their cultural framework and institutions-much of which are linked to cattle. ${ }^{39}$ Deng notes that normative human rights principles are grounded in the pursuit of human dignity, and that the concept of human dignity links Dinka culture with universal human rights. ${ }^{40}$

He explains the Dinka conception of human dignity, yet acknowledges that there are marked differences between cultures in terms of what comprises human dignity. Moreover, there is a need to be sensitive to particular cultural contexts, values, and concerns. Thus, "[t]o argue for the principle of universality is not to deny the significance of the cultural context for the definition." ${ }^{41}$ Nevertheless, Deng shows how the Dinka's traditional values are consistent in most respects with international human rights principles. ${ }^{42}$ Dinka culture recognizes a strong sense of worth and dignity in every person, with the idea of "respect" for each individual of great significance. This

Context: Law, Politics, Morals 539, 544-45 (3d ed., 2007); Randall Peerenbloom, Beyond Universalism and Relativism: The Evolving Debate About "Values in Asia," 14 IND. INT'L \& Comp. L. Rev. 1 (2003); John J. Tilley, Cultural Relativism, 22 Hum. Rts. Q. 501, 501-07 (2000).

37. See, e.g., Boaventura De Sousa Santos, Toward a Multicultural Conception of Human Rights, in Moral Imperialism: A Critical Anthology 39 (Berta Hernandez-Truyol ed., 2002); Boaventura De Sousa Santos, Towards a New legal Common Sense: Law, Globalization and Emancipation 269, 295-301 (William Twining \& Christopher McCruden eds., 2d ed. 2002). Arguing that both universalism and relativism are philosophically weak concepts, Santos calls for cross-cultural dialogues as the central condition for the transformation of human rights into a genuinely authentic cosmopolitan language. He further calls for a new approach to human rights generally. See also Makau Wa Mutua, The Complexity of Universalism in International Human Rights, in HumAn RIGHTS WITH MODESTY: THE Problem of Universalism 51 (Andras Sajo ed., 2004); Jack Donnelly, Cultural Relativism and Universal Human Rights, 6 Hum. Rts. Q. 400 (1984); Robert D. Sloane, Outrelativizing Relativism: A Liberal Defense of the Universality of International Human Rights, 34 Vand. J. Transnat'L L. 527, 559-60 (2001).

38. See Southern Voices, supra note 1, at 1, 6, 36, 45, 64, 110-14, 120-23, 135-36, 186-88. See also Mutua, The Ideology of Human Rights, supra note 35.

39. SOUthern Voices, supra note 1 , at 10.

40. Id. at 6 .

41. Id. at 42 .

42. Deng acknowledges, however, that some aspects of Dinka culture are not reconcilable with international human rights. Yet, they are changing. This includes Dinka social hierarchies based on descent, age, culture, and sex. Id. at 41, 46, 51-52. Deng additionally proffers a set of tactics to deal with the treatment and status of women. Id. at 8 n.12. 
ideal pervades the Dinka social system, which is grounded in the ideas of kinship, property, and welfare ties. ${ }^{43}$

Dinka moral and social norms are expressed in the fundamental normative principle known as cieng, "a concept of ideal human relations, which fosters deferential treatment, unity and harmony." ${ }^{\prime 4}$ Cieng provides standards for evaluating behavior while the principle of dheeng categorizes people in relation to that behavior. ${ }^{45}$ An example of how ideas and values must be comprehended within a particular cultural context is seen with the understandings of wealth and poverty. For the Dinka, prosperity and power must contribute to moral and social ends or else they do not confer dheeng on the holder. These two primary values foster solidarity and correlative relationships that reconcile economic distinctions. ${ }^{46}$

An-Na'im too speaks to the universality of international human rights within a different cultural context: that of Islam, and Shari'a in particular. ${ }^{47}$ He advocates a liberal modernist interpretation of Islam so as to reconcile and create a positive relationship between Shari'a and international human rights. ${ }^{48} \mathrm{An}-\mathrm{Na}$ 'im, a follower of the late Sudanese Mahmud Mohamed Taha, provides a straightforward exposition of Islamic history as well as an Islamic vision of universal human rights. ${ }^{49}$

An-Na'im maintains that historical Islamic Shari'a law, known to Muslims today and based in part on texts from the Prophet Mohammed's time in the town of Medina, does discriminate on grounds of sex and religion..$^{50}$ In particular, although Shari'a principles have no fundamental problems with the majority of human rights norms, ${ }^{51}$ radical reform is needed due to a number of serious inconsistencies with international human rights standards. These relate to discrimination against women and non-Muslims, freedom of religion, and slavery. ${ }^{2}$

An-Na'im argues convincingly that sufficient reform of Shari'a in relation to universal human rights can be achieved by understanding Shari'a differently. ${ }^{53}$ At present, Shari'a — which is a particular historical interpretation of Islam-is based on the Qur'an and the Sunnah. These are the first and second sources of Shari'a, respectively. The Sunnah relates to texts "of the second

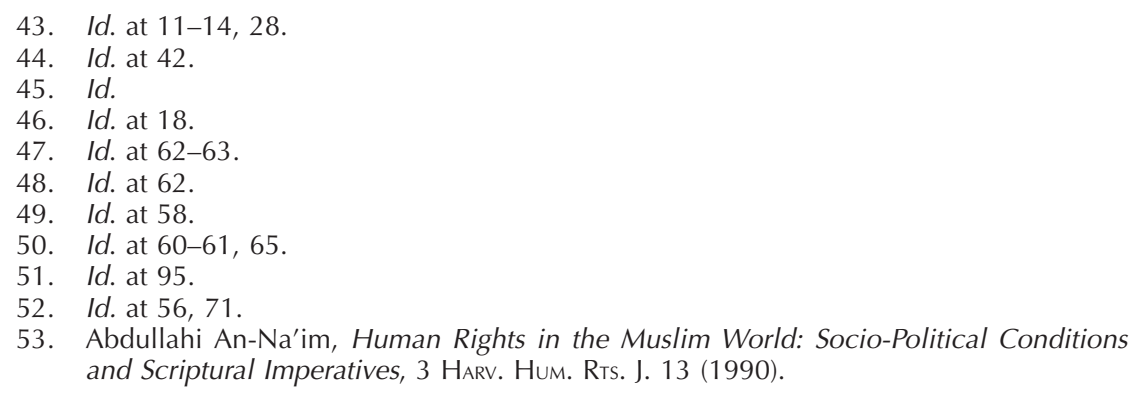


stage" discussing the Prophet Mohammed's explication and application of the Qur'an for Muslims in historical times when the Prophet was in the town of Medina. ${ }^{54} \mathrm{An}-\mathrm{Na}$ 'im notes that the Sunnah includes elements of discrimination, as noted above. However, he argues that the Sunnah must not be viewed as the entirety of Islam but simply a transitional stage of Islamic law that was a product of its historical context. ${ }^{55}$ Islam was first offered in the town of Mecca ("the first stage") where the Prophet spoke of equality and individual responsibility between all human beings with no discrimination on the basis of race, sex, or social origin. ${ }^{56}$ That message was rejected in the practical conditions of the period. The Prophet then had to migrate to Medina, where some aspects of the message were altered in response to the socioeconomic and political realties of the time. Although acknowledging that his views are appreciated by only a small minority of Muslims today, An-Na'im seeks to make the earlier texts of the time when the Prophet was in Mecca-which were previously not made legally binding - the basis of modern Islamic law. This adaptation would allow for the development of full equality and freedom for all, regardless of sex or religion. ${ }^{57} \mathrm{An}-\mathrm{Na}$ 'im's general argument also includes a call for institutional separation of Islam and the state. ${ }^{58}$

Drawing on experience from postcolonial constitution-making in India, Canada, South Africa, and Fiji, Ghai notes that human rights discourse provides a workable framework for negotiating political and constitutional settlements among leaders representing diverse group interests in multi-ethnic societies. Human rights are also useful as an organizing matrix in mediating competing ethnic and cultural claims. ${ }^{59}$ In terms of the permeation and perceptions of international human rights on the ground within each state, Ghai's empirical case studies suggest that there are divergences in group or individual perceptions and endorsement of human rights. Ghai argues that differences in views may be affected by one's socioeconomic or class position as government officials, NGOs, traders, peasants, employers, minorities, and majorities all probably view human rights differently. ${ }^{60}$ If so, the view that universalism is advocated only by those from the global North appears to be overstated.

As to on-the-ground implementation of human rights policies, Ghai argues that globalization has had a negative effect. Global competitiveness

54. SOUTHERn Voices, supra note 1 , at 60.

55. Id. at 71,77 .

56. Id. at 59, 63, 77-78. Shari'a was created through jurists' interpretations primarily of the Qur'an and Sunnah during the eighth and ninth centuries A.D.

57. Id. at 58-63, 71 .

58. Id. at 55.

59. Id. at 112-13.

60. Id. at 121-22. Ghai too notes the problematic concept of "culture" as well as the fact that the meaning and ideologies of rights have evolved over time, with diverse political systems using the concept of rights differently. Id. at 112-15, 120-23. 
and market forces have provided greater power to international institutions and transnational corporations as well as their investors and governments vis-à-vis other nation states. States-which provide the main foundation for human rights-consequently have less funds and power to create and implement adequate policies for protecting human rights, particularly social, economic, and cultural rights. Further, domestic laws and government policies are increasingly affected by global influences. In this way, democracy has also been weakened. ${ }^{61}$

Baxi provides rich and insightful critiques primarily related to macrolevel debates and present day realities of contemporary human rights. His writings elegantly highlight impediments and risks to the fulfillment of the promise of human rights. ${ }^{62}$ Baxi discusses seven themes: (1) the "modern and contemporary" genealogies of human rights and their logic; (2) the modes of production and overproduction of human rights principles and standards, including various ways of understanding this phenomenon; (3) issues of identity and difference, which underscore the ability for universal human rights to be repressive; (4) the post-modernist questioning of the recounting of global meta-narratives; (5) the resurfacing of universalism versus ethical and cultural relativism debates, the latter allowing for much human suffering; (6) the risk of human rights movements becoming human rights markets; and (7) the development of a trade-related human rights paradigm overtaking that of the UDHR as a result of globalization. ${ }^{63}$ Resonating with Ghai, Baxi argues that we must halt the current human rights paradigm shift from that of the UDHR focused on human dignity and well-being, to one that focuses on global capital and corporate well being, rejecting any material redistributive role for the state. ${ }^{64}$

Baxi notes positive and negative aspects of both sides of the universalism versus cultural relativism debates. He critiques claims that international human rights ignore cultural diversity by demonstrating that contemporary human rights are dialogically created. This often occurs through negotiation between NGOs and governments, whereby culture and religious practices are taken into account. ${ }^{65}$ Baxi also discusses the quality of human rights standards and their extended breadth, covering material as well as nonmaterial needs. However, he highlights difficulties in converting needs into rights. Baxi further underscores the hierarchical control over rights produc-

61. Ghai provides the example of Asia to support the argument that in situations of poverty, many human rights are out of reach as the poor are easily exploited. Moreover, efforts to bring corporations in line with human rights standards through self-regulation mechanisms have largely failed. Id. at 137, 146, 148-49.

62. Id. at $160-61$.

63. Id. at 164 .

64. Id. at $175,197-199$.

65. Id. at $172,186-88$. 
tion within the human rights system. He analyzes the issue of how human rights violations are determined. In doing so, he uncloaks traditions (or "discursive formations") themselves as codes masking power and hierarchy as the way in which discursive formations occur (e.g., who may speak and what forms of discourse are proper) determines what shall count as a violation of human rights. ${ }^{66}$

In relation to the practice of protecting and advancing international human rights, Baxi mounts a strong critique. He argues that human rights entrepreneurs and technocrats commodify and professionalize human rights discourse and human suffering in order to package and sell it according to what the markets will allow. ${ }^{67}$ This requires access to capital, national and international support networks, the use of public relations, mass media, etc., causing problems of legitimacy and independence for Southern NGOs. ${ }^{68}$ Consequently, Baxi argues that human rights movements of all levels (global, regional, national, and local) are at risk of becoming human rights markets, with associated difficulties for state regulation. ${ }^{69}$ Moreover, such markets would result in losing connection with the needs and experiences of suffering of those who should be both the main authors and beneficiaries of human rights: the poor and the oppressed..$^{70}$ Thus, Baxi critiques much of the discourse and many of the current practices relating to human rights. Instead, he aims to portray human rights as phenomena embedded in the experiences of suffering. This, which Baxi terms "critical human rights realism," should be used as a resource for the poor and oppressed in their fight for a better life. ${ }^{71}$ Indeed, Baxi argues that the visibility and voices of those suffering are of prime importance for international human rights. ${ }^{72}$

\section{THE NEED FOR MORE PERSPECTIVES FROM THE GLOBAL SOUTH}

Expanding on Baxi's last point noted above, this part links some of the arguments on present realities and practices of human rights proffered in both reviewed books to norm diffusion theory in the international relations and sociolegal literature and to vernacularization theory in the law and anthropology literature. Like both volumes, these theories relate to the permeation of international human rights norms to grassroots levels. ${ }^{73}$ In so doing, this part highlights important gaps in the human rights literature and makes the

66. Id. at 166

67. Id. at 194 .

68. Id. at 192-93.

69. Id. at 197-98

70. Id. at $2,168,173$.

71. Id. at 161-62.

72. He notes seven methods of how this might be realized. Id. at 195-96.

73. See Risse \& Sikkink, supra note 23; KECK \& SIKKINK, supra note 23; Sikkink, supra note 23; Human Rights and Gender Violence, supra note 23. 
argument for greater inclusion of both ordinary Southern voices and typical Southern realities within the human rights debates.

Norm diffusion theory attempts to explain the internalization of international human rights principles domestically to state institutions, state actors, and ultimately to the polity at large. Through an examination of various case studies, Risse and Sikkink proffer a theory on the phases and conditions under which international human rights rules, norms, and principles embodied in the UDHR are internalized and applied in domestic practices. This is done through a process of "socialization" whereby beliefs about right and wrong are ultimately internalized by the polity. The socialization process is influenced by networks of national as well as transnational actors, including advocacy groups connected to international organizations that galvanize domestic NGOs and affect their strategies. ${ }^{74}$ Risse and Sikkink formulate a five-phase causal spiral model relating to the workings of norm diffusion for human rights change. The final stage in the spiral model, which they term "prescriptive status," relates to rule-consistent behavior. Risse and Sikkink argue that this final stage in the socialization process is possible only when national governments are continuously pressured to abide by their commitments by those from both above and below. Human rights principles then become norms in terms of collective comprehensions and expectations of appropriate conduct, which affect individuals' behavior. When this transition occurs, external pressure is no longer necessary to ensure compliance. ${ }^{75}$ At this point, "international human rights norms will be fully institutionalized domestically and norm compliance becomes a habitual practice of actors and is enforced by the rule of law." ${ }^{76}$ This is when it can be said that international human rights norms have been internalized. ${ }^{77}$

Ryan Goodman and Derek Jinks similarly proffer a sociological theory on the effects of human rights treaties. They too focus on mechanisms of state change, which involve social pressure. Goodman and Jinks argue that international human rights treaties result in government compliance with higher human rights standards. This compliance occurs due to a social process they term "acculturation," whereby states adjust to their international situation, copying characteristics of other states. Individuals are socialized about human rights, and civil society then pressures governments to observe human rights. Although changes do not normally result in instant or major drops in human rights violations, formal changes in government organizations do have notable effects. ${ }^{78}$

\footnotetext{
74. See Risse \& Sikkink, supra note 23 , at $2-5$.

75. Id. at $1,4,7-8,11$.

76. Id. at 33 .

77. See id. at 1-5, 7-8, 11. See also KeCK \& SiKKINK, supra note 23; Sikkink, supra note 23.

78. See Ryan Goodman \& Derek Jinks, International Law and State Socialization: Conceptual, Empirical and Normative Challenges, 54 Duke L.J. 983, 983-84, 995 (2005), cited in StaCY, supra note 1, at 124-25. See also Ryan Goodman \& Derek Jinks, How to Influ-
} 
More recent research on social norms indicates that norms affect behavior and can result in compliance without people having to internalize them. ${ }^{79}$ However, this essay focuses on the fact that the international norm diffusion literature concentrates primarily on the interaction between transnational social movement activists and governments. The literature does not examine the boundaries between global ideas and those of local groups, and in particular does not focus on local individuals' perceptions of international human rights norms in developing world contexts. ${ }^{80}$

Vernacularization theory in the law and anthropology literature expands on norm diffusion theory relating to the permeation of human rights, taking it one level down. ${ }^{81}$ Sally Merry illustrates how transnational activists and national elites (e.g., human rights lawyers, social activists, academics, and community and NGO leaders) disseminate and translate international human rights ideas, legal categories and norms into local terms to deal with particular issues such as gender violence. These ideas and norms are then situated within local contexts, cultures, and values including structures of power and meaning. The aim is to make these ideas and norms part of local legal and grassroots consciousness. ${ }^{82}$ Merry argues that this incorporation enables human rights to be effective, as this process fosters the gradual emergence of a local rights consciousness among grassroots groups. ${ }^{83}$ However, Merry notes that it is unclear whether these translations and the dissemination of international human rights ideas actually achieve their emancipatory aims, particularly as they relate to increasing human rights subjectivities for victims of violence and others. ${ }^{84}$ Merry's work is predominantly about how human rights are translated into the vernacular. This differs from the focus of the present study. Of the other above-discussed theories on the permeation of international human rights laws and norms none include in their analyses the lived contextual realities of individuals who are the subjects of international human rights.

ence States: Socialization and International Human Rights Law, 54 DUKE L.J. 621, 626, 638 (2004), cited in Woods, supra note 7, at 72.

79. See BıCCHIERI, supra note 8 at 3; see also Woods, supra note 7, at 54, 75.

80. This was a critique of Harold Hongju Koh relating to Goodman and Jinks' theory, noting that the authors were yet to explain "internalization on the ground," in terms of real social acceptance of international human rights principles. See Harold H. Koh, Internalization Through Socialization, 54 Duke L.J. 975, 981-82 (2005).

81. See Merry, Human Rights and Gender Violence, supra note 23, at 222.

82. Merry, Transnational Human Rights, supra note 23, at 38, 42. See also Sally Engle Merry, Constructing a Global Law: Violence Against Women and the Human Rights System, 28 Law \& Soc. Inquiry 941, 973 (2003); Merry, Human Rights and Gender Violence, supra note 23 , at 1,134 .

83. Merry, Human Rights and Gender Violence, supra note 23, at 3, 134.

84. See Merry, Transnational Human Rights, supra note 23, at 38, 42, 49; Merry, Human Rights and Gender Violence, supra note 23, at 1, 3; Merry, Rights Talk and the Experience of Law, supra note 23, at 379. 
The authors in both reviewed volumes refer either directly or indirectly to the need for greater inclusion of ordinary Southern actors' perspectives in the international human rights debates. ${ }^{85}$ Deng and Ghai note that specific meanings of human rights must be grounded in local culture at grassroots levels. Deng further stresses that by seeing human rights concretely manifested in a particular context we can fully appreciate their form and content in the comparative framework of universality. ${ }^{86}$ Deng and An-Na'im argue that people must believe international human rights principles are sanctioned by their own culture and institutions. ${ }^{87}$ Importantly, Ghai further acknowledges the limited value in textual analysis and notes "the notorious distance between rhetoric and reality especially regarding human rights." ${ }^{\prime 8}$

In the same vein, one of Baxi's central themes in this and other works is that the basis of human rights is the experiences and struggles of individuals, and that human rights discourse only has value if it "gives voice to human suffering, to make it visible and to ameliorate it." ${ }^{19}$ As a scholar activist, Baxi stresses the importance of not losing touch with the experience of suffering and the needs of the poor and oppressed who, notwithstanding their exclusion, should be the main authors of human rights. Likewise, Baxi speaks of the gap between human rights discourse and the lived experiences of "culturally constituted human-ness," i.e. it is important to "humanize" human rights..$^{90}$ Baxi further argues that individual biographies of the violated must feature more prominently in human rights theory. ${ }^{91}$ This focus would serve to respond to questions such as, "Does this endless normativity [of human rights] perform any useful function in the 'real world'? [and] is there an effective communication ... among the norm-senders (the UN system), norm-receivers (sovereign states), and the norm-objects (those for whose benefits the rights enunciations are said to have been made)?"92 Indeed, Baxi stresses that "the 'local,' not the 'global' remains the crucial locus of struggle for the enunciation, implementation, and enjoyment of human rights." 93

85. Others too have stressed the importance of actors' perspectives and human rights realities. For instance, Martha Nussbaum has argued for greater knowledge of the "histories, problems and comparative successes" of individuals in relation to human rights." See generally Martha C. Nussbaum, For Love of Country 6 (1996).

86. See SOUthern Volces, supra note 1, at 42, 215.

87. See id. at 37.

88. Id. at 131 .

89. Id. at 164 .

90. Id. at $164-65,173,189,215$.

91. Id. at 185 n.80.

92. Id. at 176 .

93. Id. at 183-85. In another work, Baxi too notes, "[t] he real birthplaces of human rights are far removed from the ornate rooms of diplomatic conferences and are found, rather, in actual sites (acts and feats) of resistance and struggle." Upendra Baxi, Voices of the Suffering, Fragmented Universality and the future of Human Rights, in THE FUTURE OF International Human Rights 101, 116 (Burns H. Weston \& Stephen P. Marks eds., 1999). 
Similarly, noting the many great accomplishments of the international human rights regime, Stacy asks, "why can't international human rights have more influence on the actions of individuals?" She further notes, "If there is a disconnect between global human rights values and local human rights implementation, what is the cause?"94 Indeed, it has been argued that international law relating to the protection of human rights falls apart in the domestic scene in various ways. ${ }^{95}$

Both volumes deal with theoretical aspects of human rights, as well as issues of human rights practice. Although all the authors either note the limits of textual analysis or mention the need to work from the actual perspectives of those within local cultures, none of the authors include in their arguments any actual data or voices from subaltern or other individuals or peoples who have been involved in human rights cases. Indeed, the human rights literature is replete with analyses of the macro-realities of international human rights. These are undoubtedly indispensable. However, despite some very interesting and important work relating to human rights on the ground, there is an overall dearth of interpretive accounts of ordinary individuals' actual human rights experiences, practices, and micro-realities in the developing world. ${ }^{96}$ This is notwithstanding Martin Chanock's warning that

there is typically a wide gap between those who speak for cultures and those who live the culture spoken about. While cultures are complex and multi-vocal, in the representation of cultures the voices of the elites overwhelm others. Assertions about cultures tend to be totalizing and simplifying, privileging some voices and patterns of acts and ignoring and marginalizing others. ${ }^{97}$

94. STACY, supra note 1, at 7, 27-28.

95. American Law \& Society Conference at Las Vegas: Human Rights at Mid-Century: Where the Global and the Local Meet Roundtable, with Professors Wiliam Forbath (chair), Liz Borgwardt, Mark Bradley and Kenneth Cmiel (June 2005).

96. For instance, the work of Boaventura de Sousa Santos has been influential in human rights discourse in terms of learning from and better comprehending the voices and perspectives of those in the global South. His work addresses the main issues of human rights from the perspectives of those who are socially, politically, and geographically outside of hegemonic power structures. Santos' idea of "subaltern cosmopolitanism" highlights how the oppressed articulate grievances including those relating to human rights violations, thereby challenging dominant paradigms about human rights. See $\mathrm{S}_{\mathrm{AN}}$ tos, Towards a New Legal Common Sense, supra note 37, at 177, 254. Rajagopal's work on resistance of marginalized groups is also noteworthy in this sphere. BALAKRISHNAN RAJAGOPAL, International Law From Below: Development, Social Movements and Third World resistance 10, 104-18, 233 (2003). Similarly, Merry has conducted significant work on human rights and gender violence, relating it to the practices of NGOs. See Merry, Human Rights and Gender Violence, supra note 23.

97. Martin Chanock, Human Rights and Cultural Branding: Who Speaks and How?, in CULtURAL Transformation and Human Rights in Africa 38, 39 (Abdullah An-Na'im ed., 2002), cited in Fareda Banda, Women, Law and Human Rights: An African Perspective 252 (2005). Interestingly, the authors in SOUtHern Voices are elite, male members of their societies. Moreover, they perceive themselves as "cultural hybrids," and none claim to represent or be typical of any particular group or culture. See Southern Volces, supra note 1, at 5, 158, 212-13. 
Global international human rights law is ultimately local to those involved in human rights violations; and it is what people believe in and experience that matters to them and makes a difference in their individual lives. Thus, the discourses of victims, accused, lawyers, and others involved in human rights cases in developing nations must act as a lens to contextualize and critically engage the controversies in the literature on international human rights theory and practice. Accounts from the oppressed or marginalized and those involved in their cases can elucidate local human rights perspectives, perceptions, and experiences as well as the social contexts that influence them. Without clearer knowledge of Southern actors' human rights conceptions, needs, expectations, and practices, it is arguably impossible to adequately deepen our understanding of local conditions affecting human rights practice and to appreciate what is genuinely necessary to effectuate realizable change. The fact that these voices do not feature more prominently within the debates on international human rights represents an important gap. Indeed, it has been argued that as things stand presently human rights principles remain distant from real experiences, are incapable of adequately responding to the realities of pain and suffering across the globe, and thus have had limited impact. ${ }^{98}$

What do we know of local Southern legal and lay actors' perspectives on human rights standards and on how far rights are respected in local settings within the very diverse developing world? What is the extent to which they think about and use international human rights law or norms in their practices? ${ }^{99}$ Where do they take their cases to? What types of remedies are sought and why? What are local actors' comprehensions, attitudes, expectations, needs, aims, and experiences during actual human rights case processing? ${ }^{100}$ How

98. Oche Onazi, Towards a Subaltern Theory of Human Rights, 9 Global Jurist: Advances 1 (24 Jan. 2009). Onazi argues that the interactions of individuals with human rights can profoundly shape their meaning. Thus, Onazi contemplates a subaltern theory of human rights that encompasses the role, knowledge and sources of subaltern human rights perspectives. He discusses various foundational justifications and sources that support the subaltern view of human rights. Yet, he notes that the justification for subaltern contributions to human rights may be problematic if they depend solely on the degree to which these alternative perspectives are recognized in law. International human rights law is state-centered and closed to initiatives that fall outside its scope. Thus, subaltern voices are constrained in human rights discourse. To deal with this difficulty and to support subaltern viewpoints, Onazi argues for a view of human rights from the perspective of legal pluralism in that human rights as a system is based on different sources of legitimacy. Id. at 1-3, 10-11, 22.

99. See Merry, Constructing a Global Law, supra note 82, at 973.

100. For instance, North American empirical research reveals materially divergent comprehensions and functions ascribed to legal case processing by plaintiffs and defendants on the one hand, operating from an extra-legal, therapeutic and communicatory paradigm as compared with lawyers of all camps on the other, working from a strategic, tactical paradigm. This results in a marked discontinuity of interests, language and agenda of legal versus lay actors involved in case processing, with serious results for parties. Acknowledging global similarities in legal education, socialization and practice, one might compare 
much are international human rights laws or principles utilized in lower courts and quasi-legal non-state justice mechanisms where most of these cases are heard in the global South? Do local legal and quasi-legal norms reflect things that occur at the international level? In fact, relatively little is known about how people in diverse cultural and social contexts perceive themselves and their cases in terms of human rights. ${ }^{101}$

Thus, as part of a broader analysis, this essay argues that top-down textual and theoretical discourses relating to the implementation, permeation, internal validation, or practice of human rights at grassroots levels cannot adequately capture and elucidate the textured realities on the ground of those involved in human rights cases. Individuals are subject to various non-state social orders including those of family, kin, community, and quasi-legal non-state regimes potentially wielding much power over their thoughts and actions in relation to the human rights situations in which they are involved. Knowledge at this level has the ability to inform, enhance, and innovatively engage macro-level debates on human rights theory and practice, but is equally capable of changing them. Such knowledge can further aid human rights practitioners and architects in improving respect for human rights on the ground. ${ }^{102}$ Human rights academic and practical scholarship, however, has been insufficiently imbued with these micro-realities.

Second, this essay argues that on the basis that a culturally plural universalism in human rights is an acceptable aim, there is a dire need for a new integrated analytical framework, one that is grounded not only in the perspectives of Southern actors, but that simultaneously imbeds their epistemologies within the realities of human rights case processing in the diverse legally pluralistic global South. This involves not only lower formal

these findings with legal and lay comprehensions, expectations and experiences in case processing in other jurisdictions including those in the global South. See Relis, Human Rights and Legal Pluralism, supra note 9; see also Tamara Relis, Perceptions In Litigation and Mediation: Lawyers, Defendants, Plaintiffs and Gendered Parties (2009 and 2011 paperback edition); Tamara Relis, "It's Not About The Money!": A Theory On Misconceptions Of Plaintiffs' Litigation Aims, 68 U. PIтt. L. Rev. 701 (2007); Tamara Relis, Consequences of Power, 12 Harv. Negot. L. Rev. 445, 446 (2007).

101. Merry, Human Rights and Gender Violence, supra note 23, at 2, 3.

102. See Relis, Human Rights and Legal Pluralism, supra note 9. I am not arguing that violence against women alone or in conjunction with women's unfamiliarity of human rights principles is a failure of norm diffusion. Certainly, violation of a norm is not evidence that the norm is not recognized. My argument is that the scholarly and academic literature on human rights needs to be infused to a far greater degree with ordinary actors' perspectives and realities on the ground throughout the developing world in order to more realistically engage issues relating to the permeation and actualization of international human rights. Further, it should be noted that by providing a diversity of actual actors' voices involved in numerous cases throughout India, my research averts Spivak's critique of studies' collectivizing subaltern voices, inadvertently obscuring the heterogeneity of the oppressed in the global South and entrenching their inferiority. See Gayatri C. Spivak, Can the Subaltern Speak?, in Marxism AND the InTERPREtation of Culture 271-313 (Cary Nelson \& Lawrence Grosberg eds., 1988). 
courts where most human rights cases that reach any formal courts are heard, but also quasi-legal non-state justice mechanisms where very many human rights cases are processed. ${ }^{103}$ Indeed, it is often argued that the bulk of those traditional societies view solving conflicts not through the adversarialism inherent in rights discourses and legalities, but through consensual, cooperative methods. ${ }^{104}$ Thus, human rights advocates have been advised to scrutinize closely how the poor and oppressed perceive their situations and the non-state justice mechanisms and remedies they regularly seek, which frequently provide cheap and accessible services. ${ }^{105}$

Thick descriptions from legal and lay actors involved in human rights cases, whether participating in formal justice or quasi-legal processes, will enable greater understanding of the discontinuity that exists between the lived realities and subjective experiences of human rights as compared with their normative universality. ${ }^{106}$ Such knowledge will further provide context to the normative conflicts involved when individuals are subject to overlapping legal systems or rules. These include international human rights laws, domestic laws in conformity, and laws or rules within individuals' various communities. ${ }^{107}$ This aspect of human rights practice in the shadow of the law is also insufficiently examined in the international human rights literature. ${ }^{108}$ Although noting the significance of overlapping legal and quasi-legal orders, international law scholars have generally focused on the state and not on the legal pluralism literature. ${ }^{109}$ Some argue, however, that legal pluralism is gradually being drawn upon as an emerging approach to international law. ${ }^{110}$

Legal pluralism or hybridity, the co-existence of state and non-state laws and legal or quasi-legal normative systems in one geopolitical sphere-particularly in the postcolonial world-has been well documented by scholars on both sides of the Atlantic. ${ }^{111}$ In the US, Robert Cover at Yale Law School

103. Garling, supra note 11, at 51-52. See also Relis, Human Rights and Legal Pluralism, supra note 9 .

104. See Narayan et al., supra note 16; Garling, supra note 11.

105. GARLING, supra note 11 , at 71 .

106. Id. at 53.

107. Berman, Global Legal Pluralism, supra note 21, at 1155, 1157.

108. See sources cited supra note 23.

109. Berman, Global Legal Pluralism, supra note 21, at 1159, 1175; Paul Schiff Berman, A Pluralist Approach to International Law, 32 YALE J. INT'L L. 301, 309 (2007).

110. Berman, A Pluralist Approach to International Law, supra note 109, at 302.

111. John Griffiths, What is Legal Pluralism?, 24 J. Legal Pluralism \& Unofficial L. 1 (1986); Sally E. Merry, Legal Pluralism, 22 Law \& Soc'y Rev. 869, 873 (1988); Brian Z. Tamanaha, A Non-Essentialist Version of Legal Pluralism, 27 J. Law \& Soc'y 296 (2000); Franz von Benda-Beckmann, Who is Afraid of Legal Pluralism, $47 \mathrm{~J}$. Legal Pluralism \& Unofficial L. 37 (2002); Boaventura De Sousa Santos, Law: A Map of MisReading: Toward a Postmodern Conception of Law, 14 J. Law \& Soc'y Rev. 279, 297-99 (1987). See also Santos, Towards A New Legal Common Sense, supra note 37, at 92; M.S.Vani \& Rohit Asthana, Legal Pluralism and Environmental Justice in a Rural Natural Resources Context of South Asia, Comm. On Legal Pluralism, 69-70 (31 Aug.- 3 Sept. 2009). 
notably stated that law and legal norms were something created by normgenerating communities as opposed to solely by nation states. ${ }^{112}$

New legal pluralism research and debates now encompass local, transnational and international law and legal orders. They additionally examine the effects of globalization on legal pluralism in local spheres, particularly in relation to the strengthening of non-state norms. ${ }^{113}$ One segment of that literature is more empirical, and focuses on the function of communities or local movements in using and regulating norms. ${ }^{114}$ Yet, few studies utilize

112. Robert. M. Cover, Nomos and Narrative, 97 Harv. L. Rev. 4, 43-46 (1983); Robert Cover, The Folktales of Justice: Tales of Jurisdiction, 14 Cap. U.L. Rev. 179, 181 (1985). See also Berman, A Pluralist Approach to International Law, supra note 109, at 302, 307-08.

113. Ralf Michaels, Global Legal Pluralism, 5 AnN. Rev. L. \& Soc. Scı. 243, 243-45 (2009). For background on global legal pluralism, see generally Gunther Teubner, Global Bukowina: Legal Pluralism in the World Society, in Global Law Without a State (Studies in Modern LaW AND Policy) 3 (Gunther Teubner ed., 1996); Francis Snyder, Governing Economic Globalisation: Global Legal Pluralism and European Law, 5 Eur. L.J. 334 (1999); Oren Perez, Normative Creativity and Global Legal Pluralism: Reflections on the Democratic Critique of Transnational Law, 10 Ind. J. Global Legal Stud. 25 (2003); Oren Perez, Ecological Sensitivity and Global Legal Pluralism: Rethinking the Trade and Environment Conflict (International Studies in Theory of Private law) (2004); Martti Koskenniemi, Presentation at Harvard Law School, Global Legal Pluralism: Multiple Regimes and Multiple Modes of Thought (5 Mar. 2005), transcript available at http://www.helsinki.fi/eci/Publications/Koskenniemi/ MKPluralism-Harvard-05d\%5b1\%5d.pdf; Simon Roberts, After Government? On Representing Law Without the State, 68 Mod. L. Rev. 1 (2005); Sally E. Merry, Human Rights and Global Legal Pluralism: Reciprocity and Disjuncture, in Mobile People, Mobile Law: Expanding Legal Relations in a Contracting World 215-32 (Franz von Benda-Beckmann et al. eds., 2005); Sally E. Merry, International Law and Sociolegal Scholarship: Toward a Spatial Global Legal Pluralism, 41 Stud. L. Pol. \& Soc'y 149 (2008); Ralf Michaels, The Re-State-Ment of Non-State Law: The State, Choice of Law, and the Challenge from Global Legal Pluralism, 51 Wayne L. Rev. 1209 (2005); Balakrishnan Rajagopal, The Role of Law in Counter-Hegemonic Globalization and Global Legal Pluralism: Lessons from the Narmada Valley Struggle in India, 18 LeIDEN J. INT'L L. 345 (2005); Berman, Global Legal Pluralism, supra note 21; Gunther Teubner, The Two Faces of Janus: Rethinking Legal Pluralism, 5 Cardozo L. Rev. 1443 (1992); Marc Hertogh, What is Non-State Law? Mapping the Other Hemisphere of the Legal World, in International Governance and Law: State Regulation and Non-State Law 11 (Hanneke van Schooten \& Jonathon Verschuuren eds., 2008); Santos, Toward a Multicultural Conception of Human Rights, supra note 37, at 92; Brian Z. Tamanaha, Understanding Legal Pluralism: Past to Present, Local to Global, 30 Sydney L. Rev. 375, 386-390 (2008); K. von Benda-Beckmann, Transnational Dimensions of Legal Pluralism, in Begegnung und Konflikt-eine Kulturanthropologische Bestandsaufnahme 33 (W. Fiktentscher ed., 2001).

114. For instance, it has been found that local actors may vernacularize international norms or simply invoke them for political or tactical benefit. See, e.g., The Practice of Human Rights: Tracking Law Between the Local and the Global (Marc Goodale \& Sally E. Merry eds., 2007); see also Sally E. Merry \& Rachel E. Stern, The Female Inheritance Movement in Hong Kong: Theorizing the Local/Global Interface, 46 Current Anthropology 387 (2005). On how local actors utilize or oppose nonlocal norms, possibly subverting or transforming them, see Balakrishnan Rajagopal, International Law from Below: Development, Social Movements, and Third World Resistance (2003); Rajagopal, Role of Law, supra note 114; Law and Globalization from Below: Towards a Cosmopolitan Legality (Boaventura De Sousa Santos \& César A. Rodríguez-Garavito eds., 2005). 
actors' perspectives to compare formal justice and quasi-legal regimes in terms of their translations and local uses of international human rights laws and principles. ${ }^{115}$ Moreover, there is a dearth of knowledge from the perspectives of victims, accused, their families, and lawyers involved in human rights cases in the developing world. In particular, there is little information in terms of their perceptions of the interactions or overlap between state and non-state laws and the systems they treat as law, including international law and quasi-legal normative communities. ${ }^{116}$ Such knowledge would provide a nexus to Boaventura De Sousa Santos' concept of "interlegality" whereby individuals may feel subject to different sets of laws or norms which themselves have precarious relations with each other. ${ }^{117}$

It is argued that pluralism or hybridity offers a more realistic all encompassing description of realities at grass roots levels, particularly in the global South. ${ }^{118}$ Formal justice systems may be limited in scope and have inadequate resources and reach in developing countries, adversely affecting the possibilities of international human rights laws on the ground. ${ }^{119}$ On this basis, in analyzing the permeation, implementation and grassroots realities of international human rights laws or principles at present or for the future, greater account must be taken of the fact that individuals may be regulated by various legal and quasi-legal orders and other non-state norms. These may have an effect on their thoughts or behavior in relation to human rights issues. ${ }^{120}$ Thus, further investigation is needed into how local actors understand and are affected by these various communities asserting potentially competing or conflicting norms. Indeed, it has been posited that scholars can obtain a far more nuanced understanding of the international

115. For some that draw on actors' perspectives generally. see, e.g., Merry, Human Rights and Gender Violence, supra note 23; The Practice of Human Rights, supra note 115; Galit A. Sarfaty, International Norm Diffusion in the Pimicikamak Cree Nation: A Model of Legal Mediation, 48 Harv. Int'L L. J. 441 (2007); David Szablowski, Transnational Law and Local Struggles: Mining, Communities and the World Bank (2007). See, e.g., An-Na'im, supra note 21 at $39-64$.

116. This is sometimes referred to as hybridity. See Berman, Global Legal Pluralism, supra note 21 , at 1159,1161 . In the literature on global legal pluralism, hybridity describes the situation where laws overlap without completely displacing each other. See Michaels, Global Legal Pluralism, supra note 113, at 251.

117. Santos, Law: A Map of MisReading. Toward a Postmodern Conception of Law, supra note 112, at 297-99. Santos notes that present life conditions subject us all to "porous legality" consisting of multiple networks of different legal orders that intersect. See SANTOS, Towards a New Legal Common Sense, supra note 37, at 427-38. Santos's work is sympathetic to legal pluralism and human rights. Yet interestingly, the text fails to examine possible relationships between these concepts. See Onazi, supra note 98, at 18 .

118. Berman, Global Legal Pluralism, supra note 21, at 1166.

119. Shah, supra note 5, at 221, 224-25, 228-29.

120. Drawing on the legal pluralism literature, Berman notes, "in a world of hybrid legal spaces ... . a single act or actor is potentially regulated by multiple legal or quasi-legal regimes." Berman, Global Legal Pluralism, supra note 21, at 1155. 
and transnational legal landscape by examining the numerous local settings where the norms of diverse communities operate. Focusing solely on top-down frameworks in this context inevitably results in a distortion of the wide variety of goings-on at grassroots levels. ${ }^{121}$

\section{VOICES FROM THE GLOBAL SOUTH}

In support of the arguments proffered in this essay, this part provides excerpts from a forthcoming book based on new large-scale empirical research conducted during 2005-2009 in eight states of India. Grounded in interpretive theory, the book draws on primary data from legal and lay actors discussing their understandings, perspectives, objectives and experiences in human rights violations cases of violence against women. These cases were processed in lower formal courts or quasi-legal non-state justice regimes. ${ }^{122}$ The accounts excerpted here from female victims of violence and legal actors involved in these cases act as a lens to critically analyze some of the debates in the human rights literature, including those set out in the two reviewed volumes.

In India, domestic enactments of law, specifically the Protection of Women from Domestic Violence Act 2005 (PWDVA), are in line with international human rights obligations. Further, developments relating to human rights in the higher courts, and the dissemination of human rights concepts such as "equality" and "autonomy" by transnational activists and the domestic NGO's covered in the study were evident. These NGOs, which process gender violence cases, vernacularized human rights principles and worked to make them meaningful in local contexts. Nevertheless, the discourse of victims of violence in two major cities, Delhi and Bangalore, on their motivations and objectives in formal courts and quasi-legal justice

121. Berman, A Pluralist Approach to International Law, supra note 109, at 327, 329.

122. See Relis, Human Rights and Legal Pluralism, supra note 9, for dataset details. METHODOLOGY: The research is predominantly qualitative and partly ethnographic, using a multiple case study design. Yet, it is multi-dimensional through the triangulation of methods to enhance the internal validity of the data, including systematic participant observations as well as semi-structured depth interviews and questionnaires. As to the external validity of the findings, although impossible to obtain a random probability sample in this type of research, the main sample represents natural groups based on social segmentation, being victims/plaintiffs, accused/defendants, lawyers on each side, judges and mediators, all of whom within each group share a common past experience/purpose/identity, i.e. being embroiled in these particular cases from a particular actor position. Thus, in researching the few, one can generalize thematic conclusions to others who share these common identities. A small amount of quantitative analysis was also conducted, utilizing descriptive statistics to assess percentages and proportions of particular responses and to evaluate, as far as the data permit, the strength of any associations between certain variables such as individuals' views and perceptions and their genders or actor positions. Analysis of actors' discourse was facilitated by the Atlas.ti qualitative analysis computer program, enabling grounded theory. 
mechanisms suggested little, if any, human rights "emancipation." ${ }^{123}$ When comparing victims' perceptions of and aims for "justice" in local contexts with global visions of universal human rights enshrined in the normative language of international human rights laws such as CEDAW and the ICCPR, serious discontinuities existed.

Poorer, lesser educated victims of violence who had undergone quasilegal case processing in mahila panchayats ("women's courts") under the auspices of these local NGOs, stated that they had either never heard of human rights or if they had (through hearing of them in the women's courts), lacked a basic understanding of their meaning. This trend was notwithstanding the fact that the mahila panchayat's paralegals and panches (arbitrators/ mediators) were trained in and employed international human rights principles in case processing, visited numerous villages providing inhabitants with information on human rights, displayed human rights scenarios on the walls of their institutions and distributed human rights information leaflets in local languages to parties. ${ }^{124}$

123. Women's rights as human rights were articulated in the Vienna Accord 1994 and reinforced at the Beijing Fourth World Conference on Women 1995. In India, cases involving violence against women processed in the formal justice system are generally filed in the lower courts under section 498A of the Indian Penal Code for "cruelty," section 9 of the Hindu Marriage Act 1955 (for restitution of conjugal rights), and/or under the Protection of Women from Domestic Violence Act 2005 ('PWDVA'). The PWDVA regards gender violence in the domestic sphere as a human rights issue relating to the right of a woman to lead a dignified existence. As such, the PWDVA assists India in fulfilling its international commitments under CEDAW, the main UN convention on violence against women. Having ratified CEDAW in 1993, India is obliged to incorporate it into its domestic legislation. Thus, the PWDVA symbolizes India's commitment to CEDAW and its acceptance of the recognition of women's rights as human rights. See Chowdhury, supra note 15 , at 100, 114-15.

124. The non-state 'women's courts' covered in the study are the mahila panchayats in the north of India, in and around Delhi and in the state of Uttar Pradesh, as well as the Nari Adalats in Bangalore and rural Bijapur, Karnataka, Andhra Pradesh and elsewhere in the south of India. Both conduct near identical arbitration/mediation proceedings weekly or regularly for gender violence cases that are similar to those that go through the formal court system. These include cases of food deprivation as a form of punishment (known as "starvation cases"), physical and mental torture, and rape. The women's courts are run by domestic NGOs Action India and Mahila Samakya, respectively. Both organizations receive funding and training from transnational human rights organizations and others including the UN, Oxfam, the Robert Wood Johnson Foundation, USAID, Global Rights, and the Dutch government through the Indo-Dutch Program. Consistent with norm diffusion theory, the paralegals and arbitrators in the women's courts receive regular training firmly rooted in international human rights laws and principles by various transnational actors, international entities and those from Western countries linked to this funding. This knowledge is then translated into their case processing approaches as well as into local language informative leaflets for parties and posters on the walls of their courts. The mahila panchayats are advertised to the public as an easy to reach and low cost (or free), time-saving mechanism by which women can access justice in view of India's formal court systems being notoriously backlogged and corrupt. The mahila panchayats focus is generally on poor sectors of society and marginalized populations who live in 
More educated victims who went through the formal court system had a general sense of human rights concepts, but knew little of the specifics. Moreover, the discourse of victims in both groups regularly included little or no reference to anything resembling a subjectivity that included the fundamental human rights principles of equality and autonomy. When questioned, victims were frequently of the view that these concepts were of little relevance to their life situations and case realities; and though something positive, human rights ideas were only of use on an inspirational level. ${ }^{125}$ This data provides some context to the debates on universalism versus cultural relativism, as well as those on human rights permeation and practice. ${ }^{126}$ Some examples of the discourse of poor women undergoing quasi-legal arbitrations at various mahila panchayats in and around Delhi include:

Sunita: It has been two years to our marriage. He does not work, but makes me work a lot. . . My mother-in-law also harasses me. She beats me up, makes me do all the household work. . . I I was supposed to conceive a child but they had beaten me so much that the child in my womb died. At night time my husband forces me. He forces me every night. There are lots of problems. . . . You would not believe that my brother-in-law . . . he too molests me in the night time.

Do you know about other authorities besides mahila panchayat like courts, lok adalat etc?

No, I do not know . . I I am not educated.

Have you heard of human rights or women's rights?

slum-like resettlement colonies on city outskirts. Likewise, the nari adalats are mostly successful with poorer sectors of society. Interview with Gouri Chowdhury, Action India Director, New Delhi (18 July 2006 \& 10 Aug. 2006); Interview with Naseem, Action India Senior Manager, New Delhi (18 July 2006 \& 25 July 2006); Interview with Arti Paralegal, New Delhi (19 July 2006); Interview with Dr. Neela Mukerjee, U.N. Dev. Programme, New Delhi (21 July 2006); Interview with Veena Poonacha, SNDT, Mumbai (31 July 2006); Merry, Human Rights and Gender Violence, supra note 23, at 46-47, 142, 156-57; Merry, Transnational Human Rights and Local Activism, supra note 23, at 38; International Center for Research on Women and the Centre for Development and Population Activities, Domestic Violence in India Vols. 1-5 (1999-2002) at 15, 32-65, 99, available at http://www.icrw.org/publications/domestic-violence-india-part-1; Veena Poonacha \& Divya Pandey, Responses to Domestic Violence: Government and Non-Government Action in Karnataka and Gujarat, Economic and Political Weekly, 12 Feb. 2000, at 566.

125. See Relis, Human Rights and Legal Pluralism, supra note 9.

126. These findings correlate with Merry's empirical work on poor female victims of violence in Hawaii. There victims' self-perceptions as rights-holders whose situations were violations of human rights were found to be far from universal. Merry argues that women perceive themselves as defined by family, kin and work relationships. Thus, approaching the courts for help represents an uprooting of the victim from these structures to instead taking on a new identity of autonomous self, standing alone vis-à-vis the state-something difficult to do. See Merry, Rights Talk and the Experience of Law, supra note 23, at $345,352-53$. 
What is the big deal about hearing all that? Nothing is actually followed. What can those rights be? Women are considered to be a man's shoes by all family members. . . My husband does nothing besides beating me up. . . . These rights are nothing. . . . There are a lot of things heard here. All ladies here do speak about them. . . . But my husband does not give these rights.

Kumar: My Husband, his father and mother . . . They commit cruelty on me. They used to bang my head into walls, used to beat me several times. You can see scars on my back, scratches on my neck and hands. I was subject to both mental and physical torture at my matrimonial home. I think all this happened because of my infertility...

What made you decide to get help?

My father and mother decided to approach the mahila panchayat to seek justice.

Did you go to a police station to file a complaint?

No, I have not because I was afraid that my family reputation would be at stake and the police will again harass me and my parents ...

What were you seeking when you approached the mahila panchayat?

That I be taken back to my matrimonial home with due regard and respect and I shall stay there as a respectable family member. I want to return to my matrimonial home because that is my actual home after my marriage. The matrimonial home is the actual home of every woman. It is the duty of every woman to bind her family with the thread of love and affection.

I don't know if it is relevant here-but have you heard or not heard about human rights?

No, I have never heard about human rights.

Just to see if it is relevant here- have you heard or not heard of about human rights of women?

No, never.

Chhoti: My husband drinks ... What should I do? He beats me black and blue. He beats my daughter. . . I really want things to be settled as it would be the best if I remain here with my family ... Someone told me about this panchayat so I came here... . They would listen to you and will persuade and advise your husband not to drink and will decide a compromise between both of you. That is why I came here.

Have you ever heard of "human rights"? . . that people or individuals have some fundamental rights, like, they have the right to live freely, right to education?

No.

And what about women's rights, have you ever heard about them? . . . that every woman has a right to complain to the police against her in-laws if they harass her for dowry or if they commit assault on her. 
No, however my parents have given him everything he asked.

What do you want from this mahila panchayat?

I just want that by any means my husband would accept a compromise devised by the panche between me and him. . . I I have no support of anyone besides my husband. I just want that my case should get decided peacefully agreeable to my husband so that I could also live peacefully.

Victim's Mother, Kaushalya: My daughter . . . ill fate surrounded her matrimonial home. ... She was beaten there, subjected to cruelty and tyranny and absurd allegations.

Just to see if it is relevant here-have you heard or not heard about human rights? No. . . . I have no idea about them.

Just to see if it is relevant here-have you heard or not heard of about human rights of women?

Never heard of them.

What happened at the mediation?

I liked it. . . . They asked us to explain the whole case. . . . Then the panches [mediators/arbitrators] asked the in-laws to defend and they explained their side. After listening to all, the panches decided the matter and brought before a settlement pact which was agreed to by both the parties . . . At the end of the mediation process, her in-laws apologized and realized their mistakes. My daughter accepted the verdict to return to her matrimonial home. The mahila panchayat has asked my in-laws to treat her with dignity and respect without any ill treatment. They imposed on her in-laws a fine . . I I am satisfied.

If you could change anything about the process, to better deal with disputants' needs, what would you change?

Such matters should not be made public so that the reputation of the family can be maintained. Otherwise, we have to face heavy humiliation. ${ }^{127}$

Many victims of violence, particularly those in lower socioeconomic and educational groups, enlisted quasi-legal justice systems as a means of obtaining compromise agreements with their abusers in order to peacefully return to or remain in their places of abuse. These were commonly the joint family homes of their spouses. Victims' desires for "justice" were colored by their not wanting to harm the honor of their families of origin, as well as economic issues including dowry paid by their families to the families of their spouses. Women in the developing world are frequently poor, illiterate and dominated by parents or spouses. ${ }^{128}$ Thus, it was not entirely surprising

127. See Relis, Human Rights and Legal Pluralism, supra note 9.

128. Shah, supra note 5, at 227. 
that victims' understandings of human rights and stated motivations for and perceptions of justice relating to the court or non-state justice hearings they underwent regularly corresponded with those of their family members, who partook in their hearings and were interviewed separately. In fact, the data further suggest that female victims of violence were frequently subservient not only to the families of their spouses, but also to the desires of their families of origin in terms of whether at all to approach any justice system, and if so, which one and what to seek there. ${ }^{129}$

This essay therefore argues that human rights comprehensions and subjectivities as well as the desires and perceptions of "justice" of female victims of violence in the Indian landscape, and probably in many traditional societies of the global South, are bound up intricately within local social and cultural structures including networks of family, kin and community. ${ }^{130}$ This is further complicated by issues of poverty, illiteracy, and development. For instance, there were differences found between victims of different socioeconomic groups. Those in better financial and educational situations were less willing to accept perceived inequities, whereas those in lesser educated and lower socioeconomic groups regularly repeated that notwithstanding any violence, their husbands "were their gods." ${ }^{131}$ Consequently, disempowerment appeared to be internalized on various levels. ${ }^{132}$

Female victims of violence who were more educated (college and above) generally appeared relatively more independent in their decisions of whether or not to approach a justice system, which justice system to engage, and what to seek there. They were also more broadly aware of international human rights concepts and the fact that they also pertained to women. However, they too were unaware of specifics. Moreover, these women were largely of the view that human rights ideas were predominantly of use or relevant on an inspirational and not a practical level in terms of their own case realities and life situations. For example, the following two interview excerpts are from women with higher education who processed their cases in the Bangalore courts of south India.

Kumar: There was physical ill-treatment and there were times when it was too severe and ... I was admitted to the hospital. ... It was something that happened almost every day. ... . It was my husband but . . . in the midst of the abuse, his mother, who is a widow, also joined him and both of them basically beat me up.

129. Interestingly, Ghai posits that the empowerment that consciousness of rights has brought to women, peasants, workers, disabled, is amongst the strongest threats to discriminatory and oppressive cultural beliefs and practices, although the traditional forms of deference and obedience still have a powerful hold in many places. SOUTHERN VOICES, supra note 1, at 137 .

130. On enculturation within particular societies, see Brems, supra note 10, at 156 .

131. See Relis, Human Rights and Legal Pluralism, supra note 9.

132. This resonates with Ghai's argument that individuals' perceptions of rights are affected by their socioeconomic position in society. See Southern Volces, supra note 1, at 113. 
Did you go to a police station to file a complaint?

Yes . . . the 498A proceedings . . . are still ongoing . . .

What help did you want?

I was seeking a quick resolution to this case in terms of judicial separation from my husband.

Were you seeking punishment?

Punishment? No. I don't think there is a point.

Compensation?

I don't want that. I feel I am independent enough.

Have you heard about human rights?

I have to a very limited extent, yes.

Where and how exactly did you come to hear about them?

Magazines and I suppose whatever knowledge I had through school.

How do you understand what they are about?

About equality basically, in its way outmoded and I suppose a very naive concept. I suppose that is what human rights is about.

Do you think any of these human rights affect you or your dispute at all?

Human rights in general, I don't think so. I think they are very culturally specific sort of concept and so, yeah every culture has what is called its human rights ...

Have you heard about human rights of women?

Yeah, very general again . . . through magazines and recent news reports . . . when caught in a patriarchal set up it is the women's rights that have been taken away, and we were made to believe that they don't have any rights. So, it is an eye-opener.

Devika: I was subjected to ill treatment of my husband and in-laws also. . . . They used to harass me for dowry . . . and . . . a bracelet. . . I I was subject to physical ill treatment by husband and sister in law . . . and of course baby aggravated the situation more . . . because they always were expecting a boy child. . . . When I spoke to my parents, they were very supportive . . . and accepted my idea of going to the court.

Did you go to a police station to file a complaint?

Yes. ... But . . . there was not much investigation.

Was an FIR [First Information Report] filed?

Yes ... and s.498A proceedings ... Hindu Marriage Act . . and some Violence Against Women Act. 
Just to see whether they are relevant or not, have you heard or not heard of human rights?

Yes ... through TV, newspaper, and articles. ... It keeps on coming up every other day how the rights are violated.

How did you understand what they actually are?

Depending upon the circumstances it changes from person to person. . . . I think human rights should be brought out in my case too. My individual feelings were never respected in my in-laws house. That is also a part of human rights.

What do you think about the workings of the human rights of women in these cases?

No idea. But the way they are bringing them out is good. People get enlightened about it. ${ }^{133}$

In addition to victims' discourses, preliminary analysis of primary data from non-state justice arbitrators/mediators as well as legal actors working in the lower criminal and civil courts suggested that on another, perhaps unexpected level, there were further issues complicating the acceptance and application of international human rights principles on the ground within the formal justice system. The bulk of lawyer advocates and judges processing violence against women cases in the court-linked lok adalat mediations appeared to be employing international human rights principles to a far lesser extent, if at all than did the quasi-legal mediators/arbitrators (panches) in the mahila panchayats who had not received formal legal education. Many lower court judges and lawyer advocates did not feel that CEDAW or, in fact, international human rights principles at all were directly relevant to their cases involving gender violence. Thus neither the language nor the principles of international human rights were utilized in case processing. For example:

Delhi Lok Adalat Court Lawyer-Mediator: I know human rights are part of the LL.B . . . I've never heard of CEDAW. It's not relevant here. It's not used. It's mostly the tradition used.

Jalna, Maharashtra Lok Adalat Court Lawyer-Mediator: We use common sense and tradition to resolve cases ... not formal law or human rights or international laws. It's not necessary.

Hyderabad Judge \& Lok Adalat Court Lawyer-Mediator: Are human rights relevant here?

Not directly.

133. See Relis, Human Rights and Legal Pluralism, supra note 9. 
Mumbai Lok Adalat Court Lawyer-Mediator: The most important thing here is the local tradition and status of the family in society. You apply those standards in the case. ${ }^{134}$

In contrast and somewhat paradoxically, the non-lawyer arbitrators/mediators in the quasi-legal justice systems studied around Delhi,_-many of whom had poor literacy skills_-generally appeared far more geared towards resolving cases utilizing principles of international human rights law, and CEDAW in particular, as opposed to simply following local tradition or custom. ${ }^{135}$ For example, the following are interview excerpts from panches (non-state quasi-legal arbitrators/mediators):

Women's rights are human rights —-the right to live with dignity and free from violence

We are trained in human rights laws and CEDAW. . . . We go twice a month.

We use these [human rights] principles in reaching resolutions to these cases. ${ }^{136}$

This dichotomy may be a result of various factors. First, there is no mandatory continuing legal education in India for lawyers. Thus, those advocates who began practice prior to India's ratification of CEDAW in 1993 or other international legal documents might be less aware of various international laws possibly affecting their cases. Second, the quasi-legal justice mediations and arbitrations covered in the research took place under the auspices of various local NGOs. Consistent with norm diffusion and vernacularization theories, these NGOs received funding and consequently regular training in international human rights laws and principles by various international NGOs and transnational actors and entities from Western countries, such as USAID and the Dutch government through their Indo-Dutch program. ${ }^{137}$ However, evidence throughout the dataset also indicated that additional factors involving the social contexts and situations within which legal and quasi-legal actors lived additionally impacted their attitudes and conduct.

Indeed, this data further lends support to arguments that grassroots compliance with legal, international, and other norms often evinces sociopolitical actualities to a far greater extent than the legal status of those norms. Social contexts at grassroots levels, whether among legal or lay individuals,

134. Id

135. Interestingly, in articulating their mission, Action India-who run the mahila panchayats - state "We believe that women's rights are human rights." Interview with Gouri Chowdhury, Action India Director, New Delhi (18 July 2006; 10 Aug. 2006). See http:// actionindiaworld.org/pages/about-us/mission.php.

136. See Relis, Human Rights and Legal Pluralism, supra note 9.

137. See Tamara Relis, Human Rights \& Violence Against Women in India: Paradoxes in Formal Courts vs. Informal Justice Mechanisms, Presentation at the American Law \& Society Conference in Berlin, (July 2007) and the Annual Conference on South Asia, Univ. of Wisconsin-Madison (Oct. 2007). 
frequently entail systems of control and have normative influence. ${ }^{138}$ State enforcement of human rights-related laws may have little local normative purchase. ${ }^{139}$ Thus, legal rules that are incompatible with community norms or local customs may have little effect on the ground unless they are imposed by force. ${ }^{140}$ Consequently, the incorporation of human rights into domestic legislation, often held up by governments as a measure of their respect for human rights, does not by itself ensure access to those rights.

The data on legal actors may also explain the lack of expressed human rights subjectivities found in victims of violence in the dataset who processed their cases through the formal courts. Merry argues that human rights identities are difficult for individuals to take on without institutions taking these rights seriously when they are claimed by individuals. The adoption of rights' subjectivity and talk depends on experiences within individuals' social contexts and with the legal system. These experiences include those with police, attorneys, prosecutors, judges, etc., that may or may not reinforce this subjectivity and identity. Thus, it is insufficient simply to educate people about the availability of rights. Practices within legal systems must be put into place to reinforce the experience of these rights, as implementation is fundamental to establishing human rights consciousness. ${ }^{141}$ Yet, material numbers of states lack either the resources or the political desire to run effective administrations. Without effective enforcement, the law means little to ordinary people and many do not benefit from their rights. ${ }^{142}$

In offering thickly contextual perspectives of law, needs and rights bound up within social and cultural structures, the excerpts provided here offer a modest example of some of the micro-realities affecting international human rights practice on the ground in a developing world context. The data further underscore the importance of understanding the dynamics of overlapping normative social fields in which individuals are constituted and socialized. These social fields consist of rules as well as various means of inducing compliance. They range from state or customary law to sociolegal spaces including community, family or other groups. In depth knowledge of these social fields furthers our understanding of individuals' attitudes and conduct in relation to international human rights laws. ${ }^{143}$

Comprehension of local actors' perspectives on human rights principles and norms, and what influences them, provides the substance necessary to

138. Woods, supra note 7 , at $107,111$.

139. Id. at 98.

140. Merry, Legal Pluralism, supra note 111, at 889; Berman, The New Legal Pluralism, supra note 21 , at 232.

141. See Merry, Rights Talk and the Experience of Law, supra note 23, at 344-45, 346-47, $368,381$.

142. GARLING, supra note 11 , at $1,7-8$.

143. Woods, supra note 7 , at 74 . 
theorize and resolve issues relating to the practice of human rights. In this way, the data serve to highlight the urgent need to incorporate such research into contemporary human rights debates in order to better comprehend Southern actors' diverse epistemologies as well as the complexity of factors affecting the micro-realities of human rights practice in the developing world. Such knowledge would provide broader scope for understanding why, notwithstanding the many successes of the international human rights regime, human rights still have difficulty in being perceived as relevant in the daily lives of many.

\section{FUTURE PROPOSALS FOR INTERNATIONAL HUMAN RIGHTS}

In terms of the future, both reviewed books include important recommendations for reform to match many of the new realities and challenges to the international human rights regime in the twenty-first century. Together, these modernized sets of perspectives and programs form a progressive agenda for justice and an important contribution to the developing field of international human rights law. This part sets out the proposals for the future put forward in Southern Voices and 21st Century together with comments drawing in part on the arguments developed in Parts III and IV above.

On a macro level, Baxi stresses the lengthy process by which only some human rights norms become operational. Thus, he seeks to achieve an optimal production of internationally enforceable human rights. ${ }^{144}$ As discussed in Part II above, Baxi additionally argues for the need to develop a plan of action to arrest the paradigm-shift whereby human rights movements of all levels_-global, regional, national, and local_are at risk of becoming human rights markets, with such markets losing connection with the needs and experiences of those suffering human rights abuses. ${ }^{145}$ Baxi does not elaborate in Southern Voices on the mechanisms by which these suggestions would be operationalized. Yet, their importance merits further consideration.

In terms of the actualization of human rights on the ground, both An-Na'im and Deng speak of the essential need to strengthen the cultural legitimacy and effectiveness of international human rights standards at grassroots levels. ${ }^{146}$ In his thesis on cultural legitimation, An-Na'im argues that people are more likely to honor and abide by normative propositions such as international human rights standards if they believe they are endorsed by their own cultural traditions. ${ }^{147}$ Thus, human rights will be viewed as

144. SOUTHERN Voices, supra note 1 , at 176-77.

145. Id. at 197, 204-05, 207-08.

146. Id. at 63 .

147. In the case of Islam, An-Na'im proposes reforms of Shari'a to make it consistent with universal human rights, but these reforms also require that Shari'a maintain its Islamic 
legitimate on the ground mainly by dialogue, debates, and struggle internal to particular cultures about the meaning and implications of basic human values and norms. ${ }^{148}$ Implicit in this argument is the fact that those within particular cultures who interpret and advance universal norms must be sensitive to the integrity and internal logic of local traditions and must rely on local norms and institutions. This sensitivity is necessary for meaningful and enduring changes in attitudes and practices. ${ }^{149}$ Within this paradigm, An-Na'im acknowledges the necessity of taking account of class, power and gender issues when deciding who is to be involved in the dialogues at both local and international levels, as all groups must be heard. ${ }^{150}$ Subsequent to this internal stage, human rights scholars and advocates should then seek cross-cultural legitimacy through dialogue so that peoples of diverse cultural models can agree on the meaning, scope, and methods of implementing these rights. ${ }^{151}$

Deng too stresses that for international human rights permeation, grassroots legitimacy, internalization and meaningful, effective, and lasting changes in attitudes and practices of those in the global South, people must be confident that human rights are sanctioned by their own cultural norms and institutions. ${ }^{152}$ This will involve education, cross-cultural communication, and practical cooperation. ${ }^{153}$ Similarly, Ghai notes that for human rights principles to be perceived as legitimate by people within various cultures, validation will need to derive from within each culture or tradition by reinterpreting texts. ${ }^{154}$ Adding to this, Ghai argues that while litigation is important, the better means of human rights grassroots change is social mobilization via international and local NGOs mobilizing rights. ${ }^{155}$

The findings touched on in Part IV above highlight two phenomena related to these proposals. First, international human rights norms were shown to be adopted and disseminated by non-state quasi-legal respected community arbitrators/mediators processing gender violence cases. The dissemination was done through various human rights information camps

legitimacy if it is to be effective in changing Muslim attitudes and policies on these issues. Id. at 63, 69-71, 75-77. An-Na'im, in another work similarly argues that human rights advocates in the Muslim world must work within the framework of Islam to be effective. An-Na'im, Human Rights in the Muslim World, supra note 53, at 13.

148. SOUTHERn Volces, supra note 1, at 80.

149. Id. at 37-38.

150. See Abdullahi An-Na'im, Cultural Transformation and Human Rights in Africa 54 (Abdullahi An-Na'im ed., 2002), cited in BANDA, supra note 97, at 260.

151. SOUtHern Voices, supra note 1, at 55, 81, 89, 91.

152. Id. at 37. In support of this, Deng notes the failure of African constitutions created by former colonizers, replete with foreign principles of liberal democracy thus lacking in domestic legitimacy. Id. at 33-35.

153. Id. at $38,44,51$.

154. Id. at 110-13.

155. Id. at 149 . 
whereby NGOs provided human rights information to thousands of villagers, through diagrams on their institution walls and via information leaflets in local languages distributed to parties and others who attended their hearings. Nevertheless, little if any human rights subjectivity was indicated in the discourse of victims undergoing quasi-legal case processing. ${ }^{156}$ The situation was not wholly dissimilar with more educated victims who used the formal courts and who had heard of human rights, particularly through the media (indicating domestic validation of international human rights principles). Second, notwithstanding relevant human rights domestic legislation for these cases (the PWDVA) and the progressive human rights stance of India's Supreme Court, legal actors processing violence against women cases in the lower courts indicated little if any use of human rights principles or language when engaged in these cases. ${ }^{157}$

These findings suggest that proposals for broader human rights acceptance, internalization, and practice in developing nations require deeper understanding and inclusion of local legal and lay actors' perceptions on their social and professional realities relating to human rights. As argued throughout this essay, greater account needs to be taken of the dynamics of overlapping normative, rule-encompassing social fields in which both legal and lay actors are embedded. These normative social fields include state law, customary law, and sociolegal spaces encompassing family, kin, and community in which individuals are constituted and socialized. Inclusion of local actors' perceptions of their social and professional realities is needed because these social fields influence people's attitudes and conduct in relation to human rights. Consequently, this knowledge is valuable in terms of theorizing and resolving issues relating to the practice of human rights, particularly in non-Western contexts.

In addressing the realities of cultural pluralism and offering a technique to precipitate internal cultural discourse, 21st Century sets out a concrete plan of action. Aiming for the internal legitimacy of international human rights ideas, treaty standards and institutions in the eyes of those living in different cultures, religions, and political infrastructures globally, 21st Century proposes the development of a hybrid regional international human rights court system to be situated between national courts and international human rights institutions. ${ }^{158}$

These regional human rights civil courts would be used to promote and ameliorate human rights standards and implementation across cultures and systems by articulating norms of conduct and their justification, and defining how they should be applied in light of local practices. At the same

156. See Relis, Human Rights and Legal Pluralism, supra note 9.

157. See Onazi, supra note 98.

158. StACY, supra note 1, at 4-5, 171. 
time, the courts would honor local social, cultural and religious values embedded in claims of cultural exceptionalism. ${ }^{159}$ To support this proposition, Stacy proffers a modified, two-pronged "margin of appreciation" as an adjudicative method for courts to balance general human rights principles with local norms. ${ }^{160}$ The "margin of appreciation" is an interpretive device utilized by the ECHR that allows for local variations of universal human rights norms. ${ }^{161}$ Stacy's modified technique would additionally enable the courts to incorporate evidence from NGOs, international trade accords, and human rights agreements as evidence of new human rights benchmarks. ${ }^{162}$

Stacy argues that these courts will be able to precipitate social change as court remedies will be directed at governments and will influence both governments and individuals through putting credible anthropological, ethnographic, and other evidence into the public domain (showing, for example, existing differences within cultures). ${ }^{163}$ This regional court system would be less vulnerable to pressures from the state than national human rights commissions, and would additionally allow for principled regional human rights variations through legal concepts. This result would be of particular significance for claims of cultural exceptionalism. ${ }^{164}$

Stacy's proposals are exciting. Regional human rights systems have been argued to be the most efficient modes of advancement of human rights globally. ${ }^{165}$ Some further posit that a hybrid court system would allow for a more diverse range of actors than those at international levels. ${ }^{166}$ Of course, due to the reality of multiple communities with differing norms, there will always be resistance to the imposition of universal principles. Thus, although a regional court system such as Stacy's may well improve local human rights situations, it will not be capable of capturing the entire field. ${ }^{167}$

In terms of the regional variation that may be accommodated by Stacy's proposed regional human rights court system, a further possible issue has been noted by Heyns and Killander. ${ }^{168}$ They highlight problems in how different regional human rights institutions handle the same rights. The authors

159. Id. at 5, 32 n.76, 35, 37-75, 170 .

160. Id. at 134-38.

161. Berman, Global Legal Pluralism, supra note 21, at 1175-76, 1202.

162. STACY, supra note 1 , at 173.

163. Id. at 176-77, 179. For example, in a female genital cutting case, a new African Court could adapt an approach used by local NGO's of affirming the underlying culture of the practice, while directing a government to set up a program advocating alternative rituals for entry into adulthood.

164. Id. at 32, 173 n.76. Stacy applies her proposed system to a number of controversial human rights issues in Chapter 6.

165. Burns H. Weston et al., Regional Human Rights Regimes: A Comparison and Appraisal, 20 VAND. J. TRANSNT'L L. 585, 621, 637 (1987).

166. Berman, Global Legal Pluralism, supra note 21, at 1166.

167. Berman, The New Legal Pluralism, supra note 21, at 238.

168. StaCY, supra note 1 , at 32 . 
note, "The question arises whether global and regional (and sub-regional) systems for international human rights monitoring strengthen, or weaken, each other ... Regional systems have the potential to detract from the universalist aspirations of the global system by posing different and indeed lower standards of protection." ${ }^{169}$ Thus, states seeking to retreat from global scrutiny could submit to less challenging regional human rights systems, subsequently arguing that they should not be subjected to further international scrutiny. Although those in the international human rights system work to avoid the problem of different or lower standards of human rights protection by regional human rights institutions, Christof Heyns and Magnus Killander argue that the proliferation of systems may alter the situation. ${ }^{170}$ This, of course, would only be problematic if standards were to drop to levels below those consistent with universal cultural pluralism. That being said, Stacy's proposals both contemplate and address this issue.

With regard to Asia, it has been argued that sub-regional systems would perform best where groups have common bonds of history and values, such as south Asia, the Middle East, and the Far East. Dialogues have occurred and continue to take place between civil society and the ASEAN on whether to establish a regional human rights system in Asia where one is lacking. ${ }^{171}$ However, some parties express concern regarding the inevitable involvement of authoritarian regimes, who might not be amenable to any regional body deemed to be probing and invasive and whose rulings would relate to the domestic conditions of human rights. ${ }^{172}$ This will be a difficult hurdle to surmount for Stacy's proposed courts as well.

Likewise, national human rights institutions that are accredited and comply with the Paris Principles are similarly situated halfway between domestic and international human rights systems. ${ }^{173}$ They are perceived as playing a critical role in the effective implementation and advancement of international human rights principles at domestic levels. ${ }^{174}$ Despite difficulties

169. Christof Heyns \& Magnus Killander, Towards Minimum Standards for Regional Human Rights Systems, in Essays on International Law in Honor of W. Michael Reisman (Mahnoush H. Arsanjani et al. eds., forthcoming 2011).

170. Id. at 43 .

171. See, e.g., Working Group for an ASEAN Human Rights Mechanism, available at http:// www.aseanhrmech.org/aboutus.html.

172. SOUTHERN Voices, supra note 1, at 124-25.

173. Andrea Durbach, Human Rights Commissions in Times of Trouble and Transition: The Case of the National Human Rights Commission of Nepal, Presentation at Human Rights in the Asia Pacific Conference at Univ. of Sydney, Australia, 1-2, 31-32 (15 May 2010), available at http://papers.ssrn.com/sol3/papers.cfm?abstract_id=1609452\#\#.

174. The Paris Principles include guidelines for the creation, terms of reference, independence and evaluation of national human rights institutions. See GarLING, supra note 11, at 4. This report was adopted by the United Nations General Assembly. See Principles Relating to the Status of National Institutions for the Promotion and Protection of Human Rights, G.A. Res. 134, U.N. GAOR, 48th Sess., 85th plen. Mtg., U.N. Doc. A/RES/48/134 (20 Dec. 
in defending their independence from national governments and civil society, there has been much recent development in national human rights institutions' application of human rights principles in domestic spheres, monitoring domestic legislation and handling human rights cases. Their recommendations and advice to governments and their agencies are frequently based on extensive investigations and inspections. However, domestic governments may not prioritize them and may even be antagonistic to human rights. This situation limits human rights institutions' effectiveness substantially. Yet, this evidences state failure to meet human rights requirements rather than a particular problem with national human rights institutions. Thus, state government cooperation may similarly be a difficulty faced by Stacy's regional human rights courts, notwithstanding their having greater independence than national human rights institutions. ${ }^{175}$

Finally, the vast numbers of human rights cases in each region would still make such a system difficult to access for many of those involved in human rights violations. Some of the earlier literature on regional human rights regimes highlights problems such as individuals' knowledge of their human rights and of the existence of mechanisms that promote and protect them, expectations that such mechanisms will provide redress, surrounding socioeconomic and political situations, and importantly, the availability of counsel or NGOs to assist in processing complaints. There is also the issue of regional courts' refusals to hear cases when domestic laws are viewed as securing complainants' rights, ${ }^{176}$ as domestic litigation mechanisms must be meaningfully exhausted. ${ }^{177}$ However, as noted in the introduction to this essay, this exhaustion requirement is frequently not realistic for many in developing nations. The issues discussed in this essay consequently underscore the necessity to further scrutinize the grassroots realities and social contexts of legal and lay actors throughout the very diverse global South in order to offer additional proposals for change generally, and in particular as they relate to domestic lower courts and non-state quasi-legal justice regimes processing large numbers of human rights cases throughout the developing world.

1993); see also Durbach, supra note 173, at 24-25; Anne Smith, The Unique Position of National Human Rights Institutions: A Mixed Blessing?, 28 Hum RTs. Q. 904, 904-5, 908 (2006).

175. Durbach, supra note 173, at 2, 31; GARLING, supra note 11, at 42; Catherine Renshaw et al., Implementing Human Rights in the Pacific Through the Work of National Human Rights Institutions: The Experience of Fiji, 40 Victoria U. Wellington L. Rev. 251, 251 (2009).

176. SeeWeston et al., supra note 165, at 614-22, 630. See also Etienne-Richard Mbaya, The Compatibility of Regional Human Rights Systems with International Standards, in HumAN Rights in Perspective: A Global Assessment (Asbjørn Eide \& Bernt Hagtvedt eds., 1992).

177. Shah, supra note 5 , at 222 . 


\section{CONCLUSION}

Southern Voices and 21st Century provide original attempts to rethink international human rights theory and practice to match the very diverse local realities throughout the globe. They will generate fascinating debates in the legal community and will serve as fundamental contributions in the timely discussion on the future of international human rights law and practice in the twenty-first century. This essay additionally aims to contribute to debates within the academy as well as to contemporary policy discussions about the disconnect between international human rights discourses and grassroots realities for many in the global South.

While in general agreement with the paradigm shifts and proposals described in both reviewed books, this essay argues that these analyses are significant, yet they require supplementation. One of the main functions of human rights is to give voice to and make visible the suffering and oppressed in order to empower them and ameliorate their situations. ${ }^{178}$ Thus, bottomup accounts from local legal and lay actors involved in everyday human rights violations cases throughout developing countries that are not captured by international organizations or the media must be immersed more fully within the dominant human rights debates. It may be that to the extent that human rights concepts depend on a social and intellectual vocabulary different from that which a given population has internalized, those concepts will be meaningless. Yet, one cannot determine whether this problem exists in a given situation conducting local empirical research. Such primary data is necessary to elucidate actors' epistemologies, social contexts, attitudes, and other micro-realities when involved in human rights cases. Domestic NGO explanations of local situations provided to various UN committees are important but, insufficient in adequately providing voice to those at grassroots levels. As such, both volumes highlight gaps inherent in much of the literature on international human rights, which represents largely topdown analyses of human rights issues.

Second, evaluations and recommendations relating to human rights practice must include the fact that large numbers of human rights cases are regularly processed in quasi-legal non-state justice regimes in the legally pluralistic global South and never reach the formal courts. There is a dearth of data from local actors' perspectives on how, if at all, international human rights norms are being deployed in case processing in non-state justice systems as well as in the lower courts of developing states where most cases that reach any formal justice systems are processed. Thus, more examples of the type of research presented here could make a valuable contribution

178. SOUthern Volces, supra note 1, at 161, 164, 212. 
to suggestions such as Stacy's regional courts in terms of designing them to maximize both external and internal legitimacy. Further knowledge from local legal and lay actors' perspectives throughout the developing world is also necessary, particularly concerning their conceptions and expectations of human rights and their perceived needs, objectives, agendas and experiences in various formal courts and quasi-legal justice systems, including their views on the interplay between the two.

In depth understanding of these issues can be accomplished through participant observations of case hearings as well as interpretive, ethnographic accounts from victims, accused, lawyers, family members, and others involved in human rights cases. This knowledge must contribute in a substantial way to macro-level conversations in all areas of human rights scholarship. Combining bottom-up legal and lay actors' perspectives on human rights cases with the realities of legal pluralism will enable a more nuanced, contextualized, and comprehensive understanding of the permeation and realities of human rights on the ground. This knowledge is critical to innovatively engage and possibly, reframe the controversies in international human rights theory and practice and to assist in effecting realizable change for the subjects of human rights in the legally pluralistic global South. 